\title{
Contemporary Gifts \\ Solidarity, Compassion, Equality, Sacrifice, and Reciprocity from an NGO Perspective
}

\author{
by Beáta Paragi
}

Online enhancements: appendix

\begin{abstract}
This study explores how nongovernmental organizations (NGOs) at the recipient end of the foreign aid relationship perceive partnership and cooperation with donors. Empirical research in the West Bank and Gaza Strip has revealed that relations established by foreign aid resemble archaic gift exchange in the extent to which both foreign aid and gift exchange evoke concepts of solidarity, equality, reciprocity, and related power dynamics. The results of the research indicate that return-gifts exist even in financially unreciprocated foreign aid relations. Recipients return the "contemporary gifts" by providing a special material (documenting and sharing stories of suffering or poverty) to the donor, which leads to the constant circulation of the gift ("aid for pain" and "pain for aid," to put it bluntly). The study draws attention to the complex social and political factors that local NGOs need to navigate to secure contemporary gifts, while it may also strengthen the validity of critical theories concerning the missing rationale behind the official aims of foreign aid.
\end{abstract}

The senses of compassion, pity, and solidarity are different but powerful forces guiding social relations between individuals, organizations, societies, and states. These emotions not only explain political actions (e.g., revolutionary motives; Arendt 1990 [1963]) but also entail benevolent gifts, foreign aid included. Giving, however, is a phenomenon that is too complex to occur without ambiguities and unintended consequences. Inspired by theories on gift, reciprocity, and social exchange (Blau 2003 [1964]; Emerson 1976; Gouldner 1960; Homans 1961; Mauss 2002 [1925]; Sahlins 1972), a huge body of literature has focused on the philosophy of the gift (Derrida 1994 [1992]; Hénaff 2010a; Osteen 2002; Pyyhtinen 2014; Schrift $1997)$, on its role in social and economic relations in general (Bruni and Zamagni 2013; Kolm et al. 2006), and on its role in international relations in particular (Baldwin 1985; Furia 2015; Hattori 2001; Kapoor 2008; Karagiannis 2004; Keohane 1986).

Foreign aid reflects, among other values, solidarity and compassion with the less fortunate within the international community. ${ }^{1}$ It aspires to connect quite distinct worlds: the developed and the developing, the peaceful and the conflictridden, and the democratic and the nondemocratic. Civil society actors (e.g., local and international nongovernmental organizations [NGOs] and grassroots organizations) play a

Beáta Paragi is an assistant professor at the Institute of International Studies at Corvinus University of Budapest (Fővám tér 8, 1093 Budapest, Hungary [beata.paragi@uni-corvinus.hu]). This paper was submitted 30 XII 15, accepted $18 \mathrm{~V} 16$, and electronically published $15 \mathrm{~V}$ 17. prominent role in this process (Anheier 2014). However, the power of solidarity lies at least as much in exclusion from as in inclusion in relations established by gifts (Komter 2005). As emphasized by McMillan and Chavis (1986:20), "as the force of sense of community drives people closer together, it also seems to be polarizing and separating subgroups of people." Foreign aid, whether financing a macro-level program or a micro-level project implemented by an NGO, is not an exception. Modern gifts or their absence influence the distribution of goods in society and hence influence justice and fairness as well (Kolm and Mercier Ythier 2006:72).

The idea of the gift is usually referred to using terms such as "grant," "donation," "aid," "assistance," or "support" in the context of international development cooperation. Although foreign aid officially aims to tackle problems of economic development, poverty reduction, or humanitarian crises, many emphasize that it should rather be understood as a contemporary form of traditional gift giving, conveying values, customs, and identity elements (referred to as "spiritual essence" by Mauss). Indeed, the modern gift is an expression of identity with people or groups that one feels solidarity with or belonging to (Anheier 2014:229; Mauss 2002 [1925]). From

1. The term "foreign aid" covers development and humanitarian assistance (grants and concessional loans) alike, but in the Palestinian context, most aid is provided through grants. Humanitarian (emergency) assistance is part of the official development assistance (ODA) in international statistics. While the terms "donor" and "recipient" usually refer to the concerned countries, they can also be applied to NGOs or private people depending on the context.

(C) 2017 by The Wenner-Gren Foundation for Anthropological Research. All rights reserved. 0011-3204/2017/5803-00XX\$10.00. DOI: 10.1086/692086 
this perspective - and applying the theory of archaic giftgiving practices (Mauss 2002 [1925]) — the ultimate goal of foreign aid is to maintain relations between the actors and to strengthen the existing power structures, even if only at a symbolic level (Hattori 2001). The question "what is the 'spiritual essence' of foreign aid?" is not only closely related to the debate on aid effectiveness ${ }^{2}$ in developing economics (Arndt, Jones, and Tarp 2010; Gulrajani 2011; Qian 2015) but also can be linked to critical arguments against foreign aid (Easterly 2006; Escobar 2011 [2004]; Kapoor 2008; Mosse 2005; Rist 2014 [2003]). Foreign aid can be effective in terms of achieving the officially stated objectives neither at the micro nor at the macro level if its rationale lies somewhere else: in the domain of social relationships (Eyben 2005). As it was formulated by Hattori, "what foreign aid is [in general, social-societal sense], in short, is more important than what it does [in particular, economic terms]" (Hattori 2003a:234).

This article explores the nature of foreign aid relationsmore specifically, the "spirit" of the return-gifts and the perception of sacrifice-from NGO "recipient" perspectives. By applying the framework of gift exchange theories (Mauss 2002 [1925]), it examines how the quality of "organizational cooperation" within the aid industry can be seen by Palestinian ${ }^{3}$ civil society actors (for the sake of simplicity, NGO recipients). Similarities between gifts and foreign aid are explored by means of qualitative analysis focusing on concepts such as exchange, reciprocity, equality/partnership, and solidarity. The findings are based on secondary research and primary data collected in the Palestinian territories - that is, semistructured interviews with stakeholders and observations in the past decade. The last round of interviews, the main source of this paper, was completed in summer 2015. Data were processed by means of "constant comparative" method (Corbin and Strauss 2008 [1991]); findings were analyzed by applying the theoretical framework of gift exchange concerned with solidarity and the role of gifts in maintaining relations between actors (Blau 2003 [1964]; Emerson 1976; Gouldner 1960; Homans 1961; Komter 2005; Mauss 2002 [1925]; Pyyhtinen 2014; Stirrat and Henkel 1997). One of the most interesting findings is how return-gifts can be conceptualized in financially unreciprocated aid relations. By focusing on mandatory elements of cooperation be-

2. On the history and reference documents on aid effectiveness, see http://www.oecd.org/dac/effectiveness/.

3. One may argue for Palestinian "exceptionalism," since it is not a state, its territory is (partially) occupied by Israel, and it does not enjoy full sovereignty. However, Palestinians would cite quite strong counter arguments (based on international law), starting with their declaration of independence (in 1988), the recognition of Palestine by almost 150 states since then, the United Nations (UN) General Assembly's resolution (11317) to accord Palestine a "nonmember observer state" status in the UN (in 2012), or the recent step to join the International Criminal Court (in 2014). In addition, foreign aid strongly interacts with power-related, political, and social issues regardless of the question or state of sovereignty. It applies to the Palestinian case, in particular, since the PNA has been among the top recipients of ODA per capita in global comparison since the early 2000s (see the OECD DAC statistics). tween organizations - by identifying documentation (appeals, proposals, and reports) as return-gifts and exploring the ways in which "sacrifice" can be understood - this work draws attention to the complex social and political factors that recipients need to navigate, especially in situations as complicated as the IsraeliPalestinian conflict.

To explore and understand the impact of aid on social relationships, business opportunities, and political processes, a growing body of literature has focused on the "anthropology of development” (Eyben 2006b; Ferguson 1990; Mosse 2005). While there have been attempts to explore the personal dimension and its relation to professional activities from the perspective of aid workers (Fechter 2014), other projects have focused on how recipients and beneficiaries think about donors and foreign aid (Anderson 2012; WHS 2014). In addition, investigating perceptions from the recipient perspective has concerned, among other examples, the Rwandan experience of having their "pain stolen" by a Canadian "audience" after the genocide (Razack 2007); the ambiguous effects of an aid project aiming to reduce child labor in the name of corporate social responsibility in Pakistan (Khan, Westwood, and Boje 2011); and the experiences of the local civil society with respect to the realities of "partnership" in Uganda (Contu and Girei 2014). With reference to the Palestinian context, studies have investigated not only recipient perceptions of and experiences with foreign aid in the West Bank and Gaza Strip (Said 2005; Wildeman and Alaa 2014; Springer 2015) but even feminist perspectives, particularly by exploring the painful fund-raising experiences of Bedouin women living in Israel (ShalhoubKevorkian et al. 2014). Much of this literature has emphasized the triumph of donor priorities over recipient interests by highlighting controversial effects of aid on recipient organizations and beneficiaries. This paper may contribute to a better understanding of how aid, which donors prefer to understand mostly in technical terms ("contemporary ceremonies"), is seen as part of (identity) politics on the recipient side. By complementing the existing literature concerned with the counterproductive political and social impacts of foreign aid, it may also strengthen the validity of critical, so-called postdevelopment social theories concerning the (missing) rationale behind the officially declared goals of foreign aid.

\section{Building Solidarity: Archaic Gifts, Contemporary Aid}

There are various forms of gift-giving - as opposed to marketexchange transactions - motivated either by altruism, selfinterest, or their various combinations (Bruni and Zamagni 2013; Kolm et al. 2006). Among other perspectives, gift-giving can be understood as a special form of social exchange $e^{4}$ that

4. The literature on the concept of social exchange concerns various theories in the field of economics, anthropology, sociology, sociopsychology, and psychology as well as their interdisciplinary combinations (Blau 2003 [1964]; Emerson 1976; Homans 1961; Polanyi 2001 [1944]; Sahlins 1972). The main difference between social and market exchange is the durability 
entails reciprocity obligations and determines power dynamics between the actors (Blau 2003 [1964]; Emerson 1976; Homans 1961; Mauss 2002 [1925]; Polanyi 2001 [1944]; Pyyhtinen 2014; Sahlins 1972). The concept of reciprocity is of utmost importance in distinguishing interested giving (Mauss 2002 [1925]) from "genuine" or "true" gifts (Derrida 1994 [1992]; Hénaff 2010a, 2010b; Pyyhtinen 2014). The social relation of reciprocity (a gift or favor motivated by another gift) can be seen as different from self-interested exchange (where each transfer is provided under the condition that the other is provided promptly; Kolm et al. 2006:25). In the context of giftgiving, it contributes to the higher good of society by maintaining solidarity among its members (Komter 2005) and controlling conflict situations (Hénaff 2010b:79).

In "archaic societies," it was the constant and uninterrupted circulation of gifts and return-gifts that provided social cohesion between the donors (the future recipients or creditors) and the recipient communities (the future donors; Mauss 2002 [1925]). As long as the receiver was willing and able to reciprocate, he proved his equality. Because of this, the practice of giving gifts has never been an innocent act. Mauss understood it as a total social fact, including not only what should be given, received, and returned but also "what is dangerous to take" (Mauss 2002 [1925]:76). Even if archaic and modern gifts are not identical, both maintain solidarity between the giver and the receiver and reflect power relations simultaneously, especially when "the recipient puts himself in a position of dependence vis-à-vis the donor" (Mauss 2002 [1925]:76). Whether the dependence is a matter of conscious decision (with vested interests?) or produced structurally is of secondary importance. The point is that it can hardly be separated from the local contexts, individual and societal norms and values, or perceptions of identities and self-esteem.

While the theory of the gift can be seen as a theory of human solidarity (Komter 2005; Mauss 2002 [1925]:ix), gifts simultaneously convey certain donor identities that may represent a threat to the recipient's status and identity (Camenish 1981:3). The acts of giving, receiving, and returning the gift usually reflect solidarity between the particular donor and the recipient. Reciprocity, however, also troubles the relations within the recipient (former and future donor) society, since gifts and their "spiritual essence" (Mauss 2002 [1925]) aim at influencing social norms, values, and identities. Material or symbolic changes may be seen as a sort of loss or sacrifice to be paid in exchange for the gift.

Gifts and gift relations cannot be understood without the concept of sacrifice and questions regarding the (im)possibility of gift (Derrida 1994 [1992]). Emphasizing that not every gift

(endurance) of relations established by exchange. Market exchange is a prompt interaction between actors that, in most cases, is without long-term consequences. The notion of social exchange, however, entails long-term consequences, builds on the principle of reciprocity, and emphasizes the importance of relationships and nonmonetary gains; it is more closely related to other concepts, such as solidarity, power, and dependency. (relation) can be conceptualized as (social) exchange (Derrida 1994 [1992]; Kolm et al. 2006; Pyyhtinen 2014), Pyyhtinen's major conceptual problem with Mauss' theory is that it did not problematize the connection between gift and exchange. In other words, "by subsuming the gift within the order of exchange, Mauss ultimately subjects the gift to the logic of debt . . he always interprets it in the framework of exchange . . . [but] as soon as there is a guarantee that a gift once given will be compensated, we are no longer dealing with the gift, but with exchange" (Pyyhtinen 2014:21-23). The "difference" between (genuine, true, non-Maussian) gift and (Maussian gift) exchange is a sort of "necessary loss" or sacrifice. In the absence of sacrifice (on the giver's side), the gift negates itself (Pyyhtinen 2014:25). In its presence, the gift becomes genuine: for there to be a true gift, the donor should not profit from the gift-otherwise, the given thing becomes merely a means of exchange or an instrument for gaining profit (Pyyhtinen 2014:25). Or, as implied in this logic, for there to be an exchange (gift exchange included), the recipient should be able to return the given thing, even if not immediately.

Reciprocity in gift relations, however, influences social cohesion and identity (not only between the giver and the recipient but within the communities of the giver and receiver, respectively; Hénaff 2010b). In other words, not only gifts but also sacrifices can circulate. Both accepting the gifts (burdened by the donor's spiritual essence or conditions formulated by the giver) and returning it (at the expense of social cohesion, norms, values, and identities) can be seen as "sacrifice." It is the obscure difference between gift and exchange embodied in the concepts of reciprocity and sacrifice, overlooked by Mauss (2002 [1925]) but identified by Derrida (1994 [1992]) and Pyyhtinen (2014:21-24), complemented with the "subtle balance of dependence and independence causing power and control to be deeply ingrained" (Komter 2005:70), that will explain the unintended consequences of foreign aid-negative externalities in economic terms ${ }^{5}$-in recipient countries and societies.

Foreign aid can be conceptualized as gift, a unique, albeit imperfect form of international social exchange between states (Eyben 2006a; Furia 2015; Hattori 2001, 2006; Kaapor 2008; Karagiannis 2004; Kowalski 2011; Mawdsley 2012). By deriving their arguments from Mauss' gift theory on gift-giving practices and applying it as an analytical tool, these authors offer critiques of foreign aid (as a system) that emphasize the role that aid plays in preserving inequalities and preventing real changes in both economic and political terms. It is seen as a "total social fact" symbolizing the essence of relations between donors and recipients. Being interested in "modernization," "global development," "international security," or "universal humanitarianism" in material and abstract or symbolic terms (Duffield 2001; Escobar 2011 [2004]; Kapoor 2008; Mosse 2005; Rist 2014 [2003]; Scott 1998), donors use aid instrumentally

5. In economics, negative externality occurs when the cost of an action (decision) is greater (and paid by someone else, such as the public) than the cost that is paid by the customer who made the decision. 
as a sort of poisonous gift to control the rest of the world. All this happens with the active participation of NGOs on both sides: under the flag of "generosity and gratitude" (Hattori 2006) in the case of development aid and as a kind of "organized compassion" (Watenplaugh 2015:4) in the case of humanitarian assistance.

Relations established by foreign aid may be compared to Maussian gift exchange in as much as they revolve around concepts such as solidarity, equality, reciprocity, and power. Contemporary gifts simultaneously reflect domination and subordination and maintain solidarity, or at least its illusion, between the donor and the recipient. Diverse public sentiments, such as compassion, pity, and solidarity upon seeing the suffering of others (Arendt 1990 [1963]; Konstan 2001), or at least their media representations, play an important role in official donor and private charity decisions concerning aid allocations (Chouliaraki 2013). Donor states and their public opinion, whether they are motivated by compassion, feelings of pity, or the sense of solidarity, are ready to make certain material "sacrifices" with the intention of alleviating others' suffering. While global public debate on foreign aid revolves around concepts of charity, philanthropy, pity, or compassion, official actors (donor states and international organizations) tend to emphasize the importance of common responsibility, shared interests, and solidarity for the sake of aid effectiveness, "our common future," or "global justice." Foreign aid, however, is rarely provided as a result of pure altruism, ${ }^{6}$ and something is almost always expected in exchange (Stokke 1995).

Indeed, contrary to the officially declared lofty objectives, many donors give aid for "themselves," not for "others," to maintain military alliances, to support business interests, or to justify moral and humanitarian beliefs (Deaton 2013). Diverse arguments against foreign aid are built on the conviction that it tends to ignore the local contexts and identities. By co-opting local elites, foreign aid takes away "things" that would not have been voluntarily given away by the recipient (Eyben 2006b; Furia 2015; Kapoor 2008). One way of doing so is to set various conditions that can be hidden or explicitly formulated (Boyce 2002; Sørensen 1995; Stokke 1995). Aid intervention, as a result, troubles the relations between the elites (recipients) and the masses (targeted beneficiaries) regardless of the size and magnitude of aid (Deaton 2013; Easterly 2006; Kapoor 2008; Mosse 2005; Moyo 2010; Rist 2014 [2003]). While it must be acknowledged that the effect of aid on political institutions may vary across different contexts (Jones and Tarp 2016), it weakens sociopolitical cohesion by making recipient governments less accountable to their people, for "the [official] givers and receivers of aid, the governments in both countries, are allied against their own peoples" (Deaton 2013:302). Implying that the primary purpose of an aid relationship is to maintain relations between the donor and the recipient (elites), this argument connects theories on gift and solidarity (known from

6. The motives and interests related to foreign aid are too diverse to be summarized here. anthropology) to the debate on aid effectiveness (the battlefield of economics and critical social theories).

The fact that foreign aid relations involve the appearance of the donor's influence and the recipient's interests simultaneously (Baldwin quoted by Hattori 2006:157) only troubles the picture. In the very moment when aid is accepted - even if it is accepted in the name of solidarity or compassion - the recipient "becomes complicit in the material order that brings [them] down" (Hattori 2006:160). However, since foreign aid remains unreciprocated in a material sense, it cannot be seen as a real, Maussian gift, but rather qualifies as a form of "symbolic domination" (Hattori 2001, 2006). As concluded by Annalisa Furia, foreign aid "is constructed as a peculiar form of gracious gift" that fails "to create a space of reciprocal recognition” (Furia 2015:112). From these perspectives, foreign aid is not reciprocated (in financial terms), maintains relations between unequals (the strong donor and the weak recipient), and fails to bring about positive changes from the beneficiaries' perspective. As such, they are gifts neither in the way Mauss interpreted gifts nor in any other "genuine" way (Derrida 1994 [1992]; Pyyhtinen 2014). But how do NGO aid recipients think about interorganizational cooperation, equality, reciprocity, and solidarity?

\section{Methods}

\section{Research Context}

NGOs and grassroots organizations are seen as channels for promoting peace, developing the economy, or providing basic services to the population if the state is weak (Uphoff 1993). The Palestinian nongovernmental sector ${ }^{7}$ is exceptionally vibrant and active, which is due to the unique historical context and the overwhelming donor interest in supporting the Oslo peace process since 1993 (Bouris 2014; Brynen 2000; Keating, Le More, and Lowe 2005; Le More 2008; Taghdisi-Rad 2011). Civil society organizations provided various services to the population well before the beginning of the peace process and the establishment of the Palestinian Authority (later known as the Palestinian National Authority; PNA) in 1994. However, it was the peace process that brought about major changes, and not only in terms of size and nature.

Due to the huge foreign interest in "supporting the peace process" and the relative abundance of funding sources, a completely new NGO sector emerged at the expense of the older indigenous initiatives. ${ }^{8}$ This "tier" of NGOs was cut off

7. For facts about Palestinian civil society, see the International Center for Not-For-Profit Law (http://www.icnl.org/research/monitor/palestine .html).

8. Not all nonstate beneficiaries are actively promoting change. Carapico (2014) provides a great overview on the differences between NGOs, government-organized NGOs, donor-organized NGOs, and so on in the region (see chapter 4, "Denationalizing Civic Activism," in particular pp. 153157). On the dilemmas that NGOs face in the region, see MERP 2000 (http:// www.merip.org/mer/mer214/). 
not only from the final beneficiaries that they were supposed to serve but also from the grassroots organizations and the PNA itself for different reasons (Jad 2007; Nabulsi 2005). The failure of the peace process, the prolonged Israeli occupation, and the donor money keeping the PNA alive means a huge challenge for the indigenous civil society (Keating, Le More, and Lowe 2005; Le More 2008; Taghdisi-Rad 2011). While NGOs are supposed to play a significant role not only in implementing projects in the field of development and humanitarian assistance but also in the "emergence of a democratic system and democratic practices in the West Bank and Gaza Strip," their role and influence has been constantly undermined by the PNA and, in some sense, by their very donors as well (Nabulsi 2005:122).

While Palestinians enjoy exceptionally strong international solidarity (if measured by ODA per capita, for example), aid effectiveness - understood more broadly and not simply in economic terms - has been acknowledged as an obvious failure in the West Bank and Gaza Strip. Donors have been criticized for maintaining the status quo (Bouris 2014; European Commission 2014; Le More 2008; Taghdisi-Rad 2011) and for their complicity in the Israeli occupation (Dana 2013; Murad 2014; Nakhleh 2004, 2013; Tartir 2014).

\section{Data Collection}

This study was based on secondary research and fieldwork. The interviews were conducted in a natural setting - in the West Bank and Gaza Strip (Palestine) - in which the NGO interview subjects actually worked. The data collection was part of a larger project tracking the recent changes in Western aid policies in Egypt, Jordan, and Palestine and how these changes have been applied in an attempt to control regional developments; to understand how Western aid policies have contributed to the "Arab Spring," and how the focus of Western aid has been changing; and, last but not least, to understand local perceptions of aid-related foreign interventions. Aspects of the broader context have been reported elsewhere (Paragi 2015a, 2015b, 2016a).

To capture the perspectives and experiences of the interviewees working with various (religious, nonreligious, humanitarian, and development) NGOs at the recipient end of the gift-like aid relationship, qualitative data were collectedand also analyzed - through a grounded theory approach (Glaser and Strauss 1967). By using an inductive approach, an initial set of substantive codes (e.g., gift-giving, exchange, and reciprocity) was identified during earlier phases of the research (Hattori 2001; Kapoor 2008; Karagiannis 2004; Stirrat and Henkel 1997). These encouraged me to interpret foreign aid relations within the theoretical framework of gift exchange (Mauss 2002 [1925]; Pyyhtinen 2014). The developing theory required me to collect additional data on how particular individuals working with implementing NGOs think about factors influencing cooperation vis-à-vis their donors as well as on how they think about the exchange aspect of the foreign grants they receive.
Interviews were a useful method for exploring these questions. The new data led to generating additional codes (such as counter-gifts and sacrifice) by applying a deductive approach.

The most recent - and from the perspective of this article, the most relevant-round of interviews was conducted in the West Bank and Gaza Strip between July and September 2015. The interviews aimed to explore the nature of relations (bonds and ties) between NGO recipients and (locally active, bigger) foreign donor organizations by means of qualitative methods. Building on earlier research that mapped local perceptions of foreign aid in Palestine (Paragi 2012a; Said 2005; Springer 2015; Wildeman and Tartir 2014), its core objective was to understand the personal-level feelings and human experiences attached to or stemming from daily interactions between organizations (i.e., between the NGO recipient and the donor organization). Altogether, 22 people were interviewed ( 9 women and 13 men; 12 people were in the West Bank and were identified as WB1-WB12, and 10 people were in the Gaza Strip and were identified as GS1GS10). ${ }^{9}$ They had rich and multiannual experience in working with various local, regional, and international aid organizations during the course of their lives. All of the interviews were semistructured; the vast majority (20) of the interviews were conducted face to face, whereas two of them were conducted via e-mail correspondence. The interviewers were native Palestinians experienced with both qualitative and quantitative data collection who worked at the Fafo Research Institute. The interviews were conducted in Arabic, recorded, translated, and transcribed. In addition to these interviews, discussions that I have conducted with various stakeholders since 2005 were also incorporated into the research (Paragi 2012a, 2012b).

\section{Related Dilemmas}

One cannot move further without reflecting briefly on dilemmas concerning the data collection. The interviews were conducted by my Palestinian colleagues living and working in the Gaza Strip and West Bank, who were affiliated with the same Western research institute that I was affiliated with. We have known each other for many years, and this was not the first project that we collaborated on. The current European Union (EU)-funded project, however, required me to adhere to certain Western norms in terms of research ethics. While the chosen data-collection method (Palestinians interviewing Palestinians) provided the highest level of confidence between the interviewer and the interviewee, it was clear from the very beginning that my colleagues did not feel comfortable with asking their interlocutors to sign anything, including a detailed informed-consent form. They found it "culturally inappropriate," undermining trust. While this was fully acceptable to me as a researcher, the European and Norwegian ethical

9. Tables containing the respondents' profiles and details of the interviews are available online in an appendix. 
authorities expected me to coordinate details of the data collection with them (as authorities) at the beginning of my project (Autumn 2013). Many of our respondents felt it either ridiculous or offensive to give a written consent, and this applied not only to the most recently collected data pertaining to the subject of this paper (Summer 2015) but also to data from earlier phases of the research project (obtained during interviews conducted with EU people in Brussels or Amman). The common experience was that it was in some sense impolite to ask for any extra "consent": if the interviewee said "yes" when he or she was approached for a potential interview to share his or her thoughts and experiences, any additional contract-like piece of paper was seen as unnecessary and perhaps even threatening.

As a researcher, I have been struggling to answer certain questions since writing my dissertation on the subject of foreign aid to Palestine: do I have the right to ask any research question if the results of the (Western-financed) research on the controversial impacts of (Western) foreign aid (see the literature listed elsewhere in this paper) have not made any difference in the Palestinian context thus far and will not likely do so in the future? In addition, as was observed by Kanbur, those "who analyze poverty and discourse about poverty, seem to do rather well out of it" (Kanbur 2011:2). This applies to the academic sector as well (Spivak 1999), especially in an era that is marked by a constant contest for public research funding. It must be acknowledged that this research, the basis of this paper, would not have been possible without generous funding from the EU and the Norwegian Research Council. My project, however has been supported by the EU not only for its academic merit and potential (i.e., my academic progress as a researcher) but because the Palestinian case-more precisely, high-quality knowledge regarding it - is of high importance for the EU. Knowledge cannot be self-serving; the Western public wants to see the results of grants provided either to recipient NGOs or to researchers doing research on them. But one might go even further by raising additional questions: is it correct to pay for an open-access article to increase citation and boost researcher popularity (Van Norden 2013) knowing that colleagues conducting the interviews worked a man-month for the equivalent of the price one is supposed to pay for an open-access option?

\section{Data Analysis}

The data analysis resulted in conceptualizing latent patterns and structures of international development cooperation - as perceived and experienced by recipient NGOs - by means of the process of constant comparison (Corbin and Strauss 2008 [1991]). First, by reading the transcripts line by line, coding was performed with the aim of identifying basic elements (codes) labeled, for example, as "conditions," "facilitators/contractors," "equal partners," "sacrifice," "stories of sufferings," "NGO influence on donors," "the role of documentation," "credibility and transparency," and so on. The second step was about identifying connections between the categories and recognizing subdialectics, such as "facilitators/contractors versus equal partners" or "sacrifice: accepting versus rejecting conditional aid." As the coding progressed, patterns started to emerge. Codes related to gift exchange were scrutinized with extra attention; for example the "documentation" (identified as returngift by the end of the coding process) was divided into two subcategories (ex ante: appeal or proposal writing; and ex post: report writing). These and other codes in line with the textual context in which they emerged were instrumental in interpreting various documents as unusual forms of return-gifts. In the third step, the subdialectics were merged into bigger categories on the basis of their content. For example, the main code "partnership" is composed of the subcodes "facilitators/ contractors" and "equal partners"; in a similar vein, "influencing factors" covers "time," "size," "like-mindedness," and the "physical presence/closeness of the donor." Finally, interview excerpts were analyzed to understand how experiences with project implementation from the perspective of the nongovernmental recipient relate to the "personal perspectives" within the aid effectiveness debate (Fechter 2014). The data offered a much broader pool of findings than can be presented and discussed here ${ }^{10}$ so only those evoking gift exchanges are described in detail in the next section.

\section{Findings}

The processed data enabled me to identify the most important concepts and patterns perceived by NGO recipients in an aid relationship, in which the donor could be an individual, a local or international NGO or official partner, a donor agency, or an international organization. Our respondents' experiences with their donors reflected on the following main features of the gift-like aid relationship: the quality of a partnership (equality, solidarity, effectiveness); the existence of return-gifts (documentation), the "reciprocal" feature of which remained largely unnoticed and unacknowledged by them; and conditions understood as "sacrifice" (the "necessary loss" on the recipient side).

\section{Equality}

Partnership in international development cooperation implies that partners have "equal standing, rights and ability to influence outcomes” (OECD 2015:57). However, attaining equality in aid relationships is not an easy task. To practice the "principle of partnership" is much more difficult than to

10. The coding table and a structured summary of the excerpts and quotations are available in an appendix. There are two additional papers that are based on the same data set (with sections describing the data collection and analysis in a more or less identical way). While Paragi $2016 b$ explores the hegemonic being of international solidarity embodied in international gifts, Paragi 2017 is concerned with certain culturerelated impacts of foreign gifts, perceptions on shame included. 
implement any aid project (Contu and Girei 2014). It is a globally shared experience that the donor takes the lead in the majority of aid relationships, whereas recipients' voices are hardly taken into consideration (Anderson 2012; Contu and Girei 2014; Deaton 2013; Easterly 2006; Khan, Westwood, and Boje 2011; Rist 2014 [2003]). Although donor assistance has helped build essential capacities since the early 1990s, critical attitudes toward aid have been influenced by the failure of the general political framework - the Oslo peace processthat that aid was supposed to support. It has been criticized not only for failing to "change the game" but also for ignoring essential, politics-related Palestinian interests on the ground (Keating, Le More, and Lowe 2005; Le More 2008; Nakhleh 2004, 2013; Taghdisi-Rad 2011; Tartir 2014). The lofty principles (such as partnership, accountability, transparency, and ownership) seen as guarantees of effective aid have been introduced and applied in Palestine as well. Experienced heads of recipient NGOs in Palestine described two major types of relationship vis-à-vis their donors. In some cases, they could play only the narrow role of "facilitators/contractors," whereas in many cases they proudly reported enjoying full equality and described themselves as "real partners" in project implementation.

Real partners. One of the most important preconditions for a "real" partnership is equal participation in decision-making. Many of our respondents described themselves as "equal partners" in decision making. As an NGO leader from the West Bank emphasized, "if you believe in [an] idea and cause that you are working towards, you can always get the point across regardless of barriers . . my experience has been that donors are not real limiting factors to our goals" (WB3). A manager of an NGO operating in the West Bank (WB4) went further, stating that "the Palestinian NGO partners are the ones that determine the relationship. If they allow the donors to influence their policies, strategies, and decisions, they lose all ability to maneuver. Donors will always want to interfere. They will always want to get most of the decision-making discretion, because they provide the funds. In our organization, we don't allow them . . . [but] we constantly prove our professionalism and dedication that can always ensure access to new funding and new donors." While it was acknowledged that "[donors] may [wish] to control and not to involve us in decision-making," there were respondents emphasizing that the nature of the relationship is mostly up to the NGO. If the recipient "let [a] donor to impose certain conditions [that are] not fair" (GS5), the donor will do so. And even if, in many cases, "relations with some donors are a constant struggle" (GS5), it was still possible to achieve a consensus. A leader of a local NGO in the Gaza Strip (GS3) explained the recipient understanding of effectiveness: "We are the decision maker, we determinate the priorities [starting with] writing the proposals [and] applying to the donors, we identify the subjects and programs [that] need to be funded, [that] fit our people's needs, according to our vision to the Palestinian sit- uation. The donors can't impose us to accept certain programs [that] do not fit our needs; they don't interfere in our internal policy and our ways of implementing the projects." Concepts such as "professionalism," "credibility," "local knowledge," "transparency," or "commitment" were widely applied to describe a "true partnership" by recipient NGOs. Typical of this relationship is the recipient's ability to "propose the project," "to assess what is needed in a certain project," and "to feel [that] we are one team" (WB6) or "we work as one family" (GS6). The perceived factors influencing successful cooperation and aid effectiveness at a micro level comprised four elements: time, like-mindedness, size, and the physical presence or closeness of the donor. ${ }^{11}$ A lot seemed to depend on the human relations between the individuals representing the organizations concerned. The longer they worked together, the more they knew each other, the more they thought alike in terms of the political context and social dimensions, and the more satisfied our respondents were with the results of the cooperation. As an NGO director from the Gaza Strip (GS1) elaborated, effective cooperation depends on the following:

[If] there is a previous friendship relation [that] grows and strengthens through frequent visits and meetings, [then] there is greater confidence [trust] between us and the [project] implementation will be much easier. [All this] will lead to successful projects, and we can reach the planned goals faster ... Donors whom we have more than one project with trust us better, so it is easier [to deal with them]. They do not wish to impose their decisions on us, because they know us well through previous experience.

While the length of cooperation obviously led to familiarity, trust and common values were also seen as decisive factors, because "like-minded organizations form better alliances" (WB4). Since "donors seek comfort and certainty" (WB8), they were reported to look for partners with similar values or political thinking. Church-related international NGOs work with Palestinian Christian organizations, because "they are considered [one] family" (WB2), whereas religious Islamic NGOs receive funding mostly from Muslim and Arab states, simply because "the[ir] culture and traditions are very close to ours" (GS9). Others reported receiving "funding from private sources and 'leftist' sources ... mostly from organizations that are ideologically close to us" (WB9). By the same token, "Saudi Arabia will never provide funds for a democratic election campaign, simply because there is no democratic election system in Saudi Arabia ... and Qatar will never support a conference for women or youth rights, because Qatar does not believe in women and youth rights" (GS2). NGO leaders, however, emphasized the less bright side as well. In less fruitful types of cooperation, local NGOs could play only the limited role of "facilitators."

11. These are discussed in depth in Paragi 2017. 
Facilitators and subcontractors. Even the most successful and strongest NGOs had experienced what it meant to be only a subcontractor. As it was explained in the Gaza Strip (GS4), "There are other donors we had worked with, but not [as] a full partner ... these donors are implementing the projects by their own staff (they have offices in Gaza). . . . we local NGOs will get very limited benefits from these projects, and less experience . . . we don't participate in the all levels of the projects, and our relation not full partnership, we just have some specific roles in the project." In such cooperation, it is the donor that either approaches the NGO or publishes a call on its website defining its own objectives and priorities, "because they have all this money they have to spend." The abundance of sources raised certain moral dilemmas (WB10): "When the foreign policy doesn't correspond with the Palestinian foreign policy, the donor tries to push you away from what you believe. This makes the Palestinian partners uneasy; it makes them feel dirty even. Some donors ask some NGOs to do their work the way they want, while including some aspects that don't relate to the goal specifically."

The most widely reported problem with the "facilitator" role was the lack of "ownership" coupled with making financially rational decisions on the recipient side. If the supply side is stronger, if the donor wants to spend its money in Palestine, it would be stupid to refuse it, even if "we don't totally agree them in [terms of] the values" (GS5). Indeed, one typical feature of the subcontractor relation was the "transaction-like" nature of the cooperation, the missing sense of community (McMillan and Chavis 1986) between the donor and the recipient, and the donors' desire to "enforce their own vision" (WB1) independently of the realities. Contrary to the perceived domination of the donor agendas in aid relationships, recipients could not but notice that most of their institutional donors were more concerned with procedures than with substance. It was a widely shared experience that donors "are interested in figures . . . in monitoring your implementation of the action plans, [they] are more concerned with their action plans" (WB2). Others went further, claiming that "donors are not necessarily concerned with the suitability of the projects that they sponsor; they are concerned with the start and end dates of their projects" (WB3). Donors' preoccupation with procedures made one of our respondents (WB3) learn "how to address the donors with the language that most suits their sensitivities politically, ideologically, and socially; you use a given vocabulary with the donor" to be effective.

Many relationships were perceived as purely "contractual and transaction," being "limited to the cooperative process, not [being about] who you are and what you are trying to do in the world; donors . . . don't truly relate to the beneficiaries in the totality of their experience" (WB10). However, regardless of the substance and nature of the relationship, "there is always an agreement [between the donor and the recipient NGO], and there is a reporting aspect" (WB10). This "reporting aspect" has long traditions in the Middle East, and since the Armenian genocide, it has intersected with the "expectations of the Western middle-class public sphere and its technocratic, disciplinarily knowledge-driven and sometimes rights-based response to humanitarian need" (Watenpaugh 2015:58). It plays a crucial "ceremonial" role in terms of attempting to prove "equality" (in Maussian terms), which will ensure (the illusion of) partnership, (at least compassion-based) solidarity, and further funding. While the "ceremonial" adjective refers to the fact that various documents are mandatory elements of institutionalized aid/gift relations, it also implies that many of these papers are not read by the donors as perceived by our respondents. This experience is one of the many factors that made recipients think that their identities and realities do not necessarily matter for their donors.

\section{Reciprocity ("Aid for Pain, Pain for Aid")}

One of the most interesting findings of this study is how return-gifts can be conceptualized in aid relations. Aid relations are said to be unilateral due to the financially unreciprocated nature of the transaction. However, as our data prove, humanitarian and development knowledge - such as documenting and sharing of pain, stories of misfortune, suffering, and underdevelopment - may well qualify as return-gifts. It must be emphasized that none of the respondents identified them as return-gifts per se. Rather, the way they explained the necessity of reporting and doing it in a transparent and credible manner implied that the very function of documentation is about returning the "gifts," on one hand, and "inviting" further aid, on the other hand. When donors "see the suffering" in Palestine, "they give aid." They can "see" it by getting various documents, such as proposals, appeals, reports, photos, videos, and so on. This "material" can be "offered" ex ante (to justify in advance why aid is needed) and can be sent ex post as a return-gift (to prove that aid was used properly and purposefully and to ensure the next installment). The distinction is somewhat arbitrary, yet it is worthwhile to take a brief look at the differences.

Ex ante documentation. Prior documentation was seen as more important in "real partnership" relations than in the "facilitator/contractor" type of cooperation, which later was seen to be based on the donors' agenda. Its most typical form is the appeal or proposal prepared at the NGOs own initiative or at the donor's request. Its purpose is to justify the needs by building on various emotions (compassion, pity, and solidarity) and the sense of justice on the donors' side. It is overtly used for fund-raising purposes in the donor country (GS5): "Many of our donor partners implemented big solidarity campaigns in their countries with us; we participated in these campaigns via Skype, and we talked to the people there about our conflict, suffering, and the destruction of Gaza."

The cause-effect logic implies that the better the donors and the population in the donor countries are informed, the deeper the humanitarian and development knowledge is and the more generous their contribution will be. The perceived causality 
was expressed in ways such as "most of the donors looking for funding crises" (GS5), and "they witnessed the suffering of the people in Gaza, [so] many of them became our supporters" (GS6), and "I always speak about the suffering which was created by occupation, by the settlers, and the wall; I believe I affected them [donors] positively" (WB6). As illustrated by this reply, the experience of political solidarity (stemming from observing the injustice of settlements, wall, and colonization practices) and the perceived sense of compassion (empathy) on the donors' sides were concepts that were hardly separable.

Ex post documentation. The most frequent form of ex post documentation is the report, which may contain a textual summary, photographs, and audio and video recordings that complete each other. Its purpose is to asses a given project implemented partially or fully by donor money. A wellprepared report is a testimony that allows the bystander donor to witness misfortune (development needs and human suffering) at the same time. Its perceived role was confined to only testifying to a sort of organizational culture, transparency, credibility, and professionalism (GS7): "after we finish the implementation of the project, we send the final report to our donor, attached with some photos or documented short film about the project; in most of the cases, we make a closing ceremony to the project, and we invite VIPs from the local community and media coverage, and we put a banner with the donor's name."

The constant "circulation of the gifts" blurs the border between the prior and the post not only in Mauss's world but also in contemporary Palestine (and elsewhere too). Reports documenting suffering, poverty, or any situation of humanitarian concern ex post may simultaneously function as an ex ante proposal. It mostly depends on the relationship between the donor and the recipient. If they work together constantlynot simply on an ad hoc project basis - compassion, solidarity, or both are upheld by constant circulation of "stories" and "support" (GS9): "For sure, the situation [in Gaza] left an impact on the people that visited Gaza . . . they provide assistance for us, especially after they watch the reports related to the war and the situation in Gaza. These reports documented the killing of children [and] the destruction of homes. For instance, during the last war, much assistance was sent to Gaza by Arab and Islamic charities. The war sights influenced them and moved [their] humanitarian feelings." As noted by another NGO leader in Gaza, "donors like these documents and use them to fetch more funding for us and for other associations" (GS10). When NGOs "gave them [to the donors], some of the photos of the injured people and the children, their damaged houses, they organized some campaign in their countries to support us, and they show our suffering to the[ir] people. This also was a positive way in order to get more funding" (GS10). This "grotesque" return-gift contributes to the constant circulation of gifts and return-gifts by ensuring public compassion, donor solidarity (at least at a rhetorical level), and the "next installment" of donation included.

\section{Sacrifice (Conditions and Conditionality)}

While our respondents looked on the task of "documenting" as part of the normal procedure, which ensures partnership, equality, transparency, effectiveness, and the continuous flow of aid, the overwhelming majority rejected aid offered under political conditions. Political conditionality (Boyce 2002; Sørensen 1993; Stokke 1995) has been a rather delicate issue in Palestine since the last parliamentary elections in 2006. Although Hamas was elected in a legitimate and democratic way, the donor community demanded that it accept three conditions formulated ex post by the Quartet on the Middle East (Taghdisi-Rad 2011). This policy backfired, and Hamas has been controlling the Gaza Strip since 2007. Since then, the Western donor countries have not required compliance to a set of overt political conditions. Nonetheless, recipients in Palestine have always been very sensitive to any perceived political conditionality, regardless of whether such conditions were formulated officially or were only "in the air."

As was acknowledged-half-sadly, half-proudly_by an NGO leader in the West Bank, "since we are committed to our Palestinian identity, we are sometimes forced to sacrifice lucrative offers [generous aid] because of political reasons." The sacrifice concerned two major areas: participating in joint projects with Israeli partners, and signing the document containing a so-called anti-terrorism clause (ATC) for getting US Agency for International Development (USAID) funds (Lazarus and Gawerc 2015). Both of these were seen as measures forcing Palestinians "to take a political position [that] could be in conflict with the Palestinian national interest" (GS3). However, not only national interests were at stake, but also much simpler ones. The Palestinian partner could pay a heavy price for participating in so-called normalization projects with Israel $^{12}$ (WB12): "Donor [demands] to interact with Israeli local institutions during the course of project implementation with the Palestinian team are interpreted by Palestinian local institutions as normalization policy, and that's very risky for the institutions, because they can easily be considered as traitors in the eyes of Palestinian public opinion and become trapped in a public scandal." Betrayal likely entails senses of shame and humiliation.

Recipient NGOs could not take this risk. Equally, the majority refused to sign the "Document of Renouncing Terrorism [ATC], therefore [they] do not get any funds from this Agency [USAID]" (GS1). As an NGO director in Gaza elaborated, "this document is unfair . . . we are a people under occupation and are not terrorists" (GS4). Indeed, the recipients in Gaza were much more exposed to the effects of hidden Western conditionality due to the rule of Hamas and the complicated political situation. As the leader of an Islamic charity (GS10) put it bluntly:

12. Paragi 2017 also discusses these results (perceptions of shame and stigma), among others, focusing on the impact of "spiritual essence" on the recipients. 
The problem with the European and American donor institutions [is] that they don't deal with us, because they are ashamed to deal with us (. . .) some of the European donor institutions asked us to change the name of the association and do not mention the word "wounded" as a condition to deal with us, other donor institutions asked us to appoint women in the Board of Directors for approval of funding of the Association. All these conditions are either political or whatever, [but they] are not accepted by us.

Politically sensitive conditions were clearly rejected by our respondents. "Normalization" projects with Israel or signing the ATC meant the extreme end; most of our respondents were not ready to "sacrifice" their identities, their personal self-esteem, or the most elementary communal (national) values for the sake of donor money.

There were, however, much softer means of donor influence that recipients considered acceptable. While donors were said to "use their power to bend the will and the goals of the NGO" by setting conditions, "NGOS [were] often forced to bend to these conditions to receive the funds" (WB10). Recipients had to comply with technical conditions constantly, such as knowing "the language of the donors, the different set of rules by which each donor operates, and the fact that you have to report funds and expenses in a foreign currency," while "donors request that you hire their consultants to receive [their] funding" (WB10). Indeed, the border between technical and political conditionality was quite narrow: "terms like Jewish terrorism or war [must be] replaced [by] more 'acceptable' terms. Or, for example, the World Bank mentions 'poor Palestinians' [instead of] referring to the occupation's role in their economic condition" (WB9). The officially preferred terms illustrate well that (official) gifts are motivated more by simple pity and compassion than by real solidarity and related responsibility. The overall impression was that many recipients "[could not] refuse these conditions because [they would] lose this aid" (GS9). Technical conditionality was seen as part of the game, part of the process of cultural colonization of the recipient (Eyben 2006b) - that is, as a sort of "sacrifice" to be undertaken for getting aid from the international community. If and when aid worked at the project (micro) level, it was not because of but in spite of the conditions. It was due to the time spent together and common experiences gained by the recipient NGO and its donor.

\section{Discussion}

Gifts, the nature of relations created by them, reciprocity, compassion, and solidarity are different but hardly separable concepts (Komter 2005); this applies to foreign aid as well. To understand how foreign aid works — or does not work - one has to study the relationship between aid and politics at the macro level (Deaton 2013:294). To understand how "contemporary gifts" work, lower levels also need to be studied: the relationship between the concerned organizations (e.g., local NGOs, grassroots organizations, donor agencies, and representative offices), on the one hand, and human interactions and social relationships within the aid industry, on the other (Eyben 2006b; Fechter 2014; Kapoor 2008). One way of approaching the topic is the so-called micro-macro problem, which concerns capacities "to explain the relationship between the constitutive elements of social systems (people) and emergent phenomena resulting from their interaction (i.e., organizations, societies, economies)" (Goldspink and Kay 2004:598). In the field of development economics, the micro-macro paradox ${ }^{13}$ suggests that, while positive impacts are reported at the micro (project) level by organizations, macro-level effectiveness (e.g., contribution to economic growth, fiscal discipline, poverty reduction, and democratic reforms) can hardly be proved on empirical grounds (Arndt, Jones, and Tarp 2010; Mosley 1987). Knowing organizational and individual experiences with aid is of crucial importance to understand the sociopolitical impact of aid on recipient societies. ${ }^{14}$

Satisfaction at the micro level is not explained only in terms of economic effectiveness, such as schoolrooms built, support for disabled people, or funding for buying uniforms so that girls can go to university. Applying for donor money and making "transparent and accountable" reports on how it was used also contribute a lot to the sense of effectiveness and trustworthiness, even if real problems were not solved (Eyben 2005). Time, as our data prove, only strengthens the organizational relationship if both sides work in a proper manner: well-written proposals and reports will yield more money, which will lead to even better-quality papers and better partnerships alike. This implies that the opposite is true as well: the less responsive and sensitive the donor is to the recipient's interests, values, customs, traditions, and identities, the less the recipient will be motivated to prepare high-quality proposals and to maintain the "infrastructure [needed] to comply with their demands" (WB10).

Paraphrasing Pyyhtinen (2014), the foreign grant is an "(im)possible aid." It is a unique combination of (Maussian) exchange and true (non-Maussian) gift. Although it remains

13. The micro-macro paradox is part of the big "aid (effectiveness) debate," which is too complex to be detailed here. See, for example, summaries by Arndt, Jones, and Tarp (2010) or Qian (2015).

14. An AidData survey from 2015 strengthens our argument on the importance of individual, human interactions in aid relations and effectiveness as well. First, "familiarity breeds favorability": government officials in recipient countries who have previously worked for a donor partner rated their advice more useful than advice from others whom they were not familiar with. Previous and longer cooperation with a given donor had a positive impact on official policymakers' perceptions on the utility of their donors' advice (Custer et al. 2015:12). Second, "helpfulness is a two-way street": official actors were reportedly more receptive to future advice from those donors that they deemed to have been helpful in earlier reform implementation: the helpfulness of the donor had an impact on whether the donor's assistance was well received at earlier stages of a policy-making process (Custer et al. 2015:12). Policymakers and practitioners working in 126 low- and middle-income recipient countries, Palestine included, were interviewed. 
unreciprocated in financial terms, aid can also be seen as an exchange-like gift (in the Maussian sense), which calls for an appropriate return-gift. The principle of reciprocity can be applied to nonmaterial or ceremonial gifts as well (Hénaff 2010b; Komter 2005:68). Regarding the activity of the implementing NGOs, working for poor, starving, wounded, or powerless beneficiaries is essential "if the giving is to continue" (Stirrat and Henkel 1997:80). There are arguments drawing attention to the differences between foreign aid and (Maussian) gifts, either because the former remains unreciprocated in a financial sense (Hattori 2001) or because it goes from the stronger to the weaker, ignores recipients' identities, and fails to change the rules of the game and to take recipient's perspectives into proper consideration (Furia 2015).

Our findings, however, showed that many NGO leaders experienced equality and considered themselves "full partners," being able to influence donor policies and priorities, even if "donor complicity" in the Israeli occupation ${ }^{15}$ is a known concern among civil society actors (Murad 2014; Tabar et al. 2015). The durability and the quality of the relationship ("partners vs. facilitators") depended on the "quality" of the return-gift (see below), which reflected the reliability and trustworthiness of the recipient. The counter-gift apparently exists, even if contemporary gifts (including foreign aid) are mostly seen as based on the denial of reciprocity by placing the recipient in a dependent position, either turning them into a passive recipient of charity (Stirrat and Henkel 1997) or making them complicit "in the material order that brings [them] down" (Hattori 2006:160). The "exact return," however, remains unspecified in many gift relations: the timing, the quality, and the magnitude or amount of exchange depends on the receiver (Miller 1995:23). Reading the findings of this paper, high-quality implementation and transparent and reliable "documentation" ensured long-lasting, reciprocity-based relationships.

Since social-exchange theories do not identify reciprocity with the strict equivalence of benefits, the "pain for aid" gift (i.e., sharing stories of sufferings, poverty, and misery) can be understood as an attempt to return aid. As illustrated by our data, the return-gift is a special "material" that can be exchanged ex ante (calling for aid/gift) and ex post (proving that the grant was used efficiently and purposefully). There is a demand for them, since citizens behind the donor states - at least in the West - are taxpayers whose money should be spent carefully abroad. They are voters whose opinion needs to be taken into consideration in governmental decisions concerning foreign aid. Furthermore, Western donors - their citizensare also portrayed as "sensitive humanitarians who feel the pain of others deeply" (Razack 2007:384). They are consumers as well, "enjoying the sense of having been a witness to great evils" in the form of documentaries and movies (Razack 2007:382), newspaper articles, television reports, online correspondence, and so on (Chouliaraki 2013). It is their right to

15. "Recipient complicity" is implied in this term (donor complicity), as long as, without recipients, there are no donors either. be informed, to see both the "causes" and the "results" of their financial support (Anheier 2014:482), and even "to feel good" while doing good (Chouliaraki 2013). To put it in different words, "what starts off as a pure gift, an act of seemingly disinterested giving . . . becomes an object or a service intimately entwined in the interested world" in the end (Stirrat and Henkel 1997:69). And the "exchanges between sufferers and nonsufferers" yield not only documentaries and news correspondence but official documents as well. Proposals, appeals, and reports are essential "ceremonial gifts," without which there will be no more aid from governments and NGOs. Paperwork is a testimony that proves organizational effectiveness and justifies donor compassion and solidarity - ironic solidarity (Chouliaraki 2013) — simultaneously. All this makes it possible to understand foreign aid relations as gift exchange, whereby the return-gift ("the spectacle of suffering" and "others' pain or poverty") maintains a sort of solidarity that is motivated by the sentiments of the donors and rewards the donor's self (Chouliaraki 2013).

Accepting and returning the gift, however, is not as innocent as it looks in light of aid effectiveness principles, such as ownership, transparency, accountability, or partnership. There is always a "burden attached" (Mauss 2002 [1925]). The dark side of gifts and foreign aid is partially explained by the fact that individuals working at recipient organizations are human beings with emotions. They "still feel," even if "we refuse to admit it," that honor plays a role by making the recipient return the gift (Miller 1995:6). The feeling of subordination to the donor, which can be both acknowledged and denied, depending on the context, is closely related to the imperative to make appropriate and obligatory return for the gift received (Mauss 2002 [1925]). NGO leaders' understanding and consent regarding the rules of the game reflects the acknowledgement and acceptance of this obligation (to be transparent, accountable, and effective to get funding).

When donors, however, fail to acknowledge that their gifts are "not for free," they simply "steal the pains of others" by consciously or unconsciously institutionalizing conceptions of Western superiority (Razack 2007, inspired by Sontag 2003). For example, "requiring Bedouin women to share their private pains in the public sphere of funding" repositioned the role of donors at the expense of the recipients (ShalhoubKevorkian et al. 2014:16). Helplessness and gratitude on the recipient side becomes a technical or technicized instrument serving donor demands and vanity (Chouliaraki 2013), which further explains the sense of humiliation on the recipient side. If the recipients (states, societies, organizations, and individuals) are unable to reciprocate in any other way (e.g., financially), they are often expected to offer the only thing they have: donor control over some part of the recipient's life and identity (Blau 2003 [1964]:22, 28, cited by Camenish 1981:4).

This control is practiced by setting conditions, by expecting "transparency" or "accountability" for the sake of effec- 
tiveness, or by expecting detailed reports to prove trustworthiness and reliability. To see the broader context, while the Palestinian Liberation Organization and Fateh were ready to sign the Oslo agreements (in 1993), Hamas refused to comply with the conditions formulated by the Quartet on the Middle East after the parliamentary elections (in 2006). The former were accused of "selling the national homeland" by many Palestinians, and the latter was further marginalized by the international community (Nakhleh 2013). Indeed, foreign aid is usually used as a "lever to promote objectives set by the donor whom and that the recipient would not otherwise have agreed to" (Stokke 1995:11-12). It leads to a sense of "institutionalized" humiliation and legitimacy problems in statebuilding "projects" (Lemay-Hébert 2009). The philosophy behind the peace process, the idea of the "dividend of peace" (Peres 1993), peace conditionality (Boyce 2002), the role played by the donors (Keating, Le More, and Lowe 2005; Le More 2008; Taghdisi-Rad 2011), and critical Palestinian views (Lentin 2008; Murad 2014; Nakhleh 2013; Tabar et al. 2015; Tartir 2014) illustrate the relevance of these arguments. Complying with political conditions was widely seen as "sacrifice" leading to humiliating compromises in exchange for foreign grants; complying with technical conditions was more seen as a sort of necessary evil.

Like NGOs elsewhere in the region (Carapico 2014:188-198), Palestinian recipients reported that they either risked their goodwill or were forced to pay a heavy price within their own community if they accepted aid with unacceptable political conditions from foreign (Western) organizations (e.g., participating in "normalization" projects with Israel or signing the USAID ATC document; Lazarus and Gawerc 2015). This risk or price was described as sacrifice ("necessary" loss) experienced on the recipient side, which is needed for distinguishing true gifts from exchange. Indeed, for there to be a (non-Maussian, real) gift, the donor should not profit from the gift (from the foreign grant), otherwise the given thing becomes merely a means of exchange or an instrument for gaining profit (Pyyhtinen 2014:25). While the donor community - charity organizations included - wants to benefit and to see the results of its investment, it fails to acknowledge the nonmaterial dimension of "exchange." The benefits can be called peace, reconciliation, humanitarian dedication, nonviolent activities, cooperation with the enemy, ${ }^{16}$ boycott, rejecting terrorism, and so on. The menu is diverse, and it is up to the identity, autonomy, and interests of the NGO to make the right choice. The point, however, is that donors simply set a price without acknowledging the "burden attached" to their gifts. This burden can be interpreted as "sacrifice" stemming either from accepting or from returning the gifts - complying with externally set con-

16. An illustrative example could be the people-to-people initiative (in 1995), which was initiated and financed by Norway in the shadow of the peace process; its primary objective was to facilitate cooperation on the basis of equality and reciprocity between Israelis and Palestinians (Endresen 2001). ditions or sharing personal stories of suffering with remote others, respectively. By conveying donor "spirits" (e.g., norms, values, culture, and truth) and by ignoring recipient identities, norms, and values simultaneously, aid will remain a self-serving endeavor testifying to the vanity of the donors.

Since the total price of organizational (NGO) or governmental decisions is to be paid by the entire recipient population, identities, social relationships, and power dynamics in the recipient society are influenced by various negative externalities (see below). They are affected by foreign aid, especially in those cases where the recipient is more liable to, more indebted to, and more interested in the donor than in the beneficiaries (NGOs) or its own population. To sum up, foreign aid can be understood as a Maussian gift as long as recipients experience equality (i.e., are real partners), it is "ceremonially" reciprocated (by sharing stories of misfortune, poverty, and suffering in the form of proposals and reports), and the gift ("aid for pain" and "pain for aid") circulates constantly. The somewhat grotesque nature of the return-gift made one of our respondent say that "people do not want donors to go away, but they wish they could do" (WB10).

This "paradox of aid" may help us understand the irrelevance of the aid (effectiveness) debate (Baele 2013; Guerin 2014; Qian 2015). The lack of satisfaction and effectiveness at a macro level can be explained by taking into consideration the negative externalities of the micro-level aid relations (Wood and Sullivan 2015). If decisions of the recipient (government or NGO) are guided by its own (individual or organizational) profit-maximizing function and not necessarily by that of the entire society (nation), certain costs shall be paid by the "whole." Looking at our data, the rejection of overtly conditional aid (signing the USAID ATC or participating in normalization projects with Israel) may minimize negative externality costs from the perspective of the recipient. Still, there are certain emotional and macro-level political costs (externalities) to be paid by the entire society (Palestinian nation; Paragi 2017).

While our respondents were sensitive to conditionality, looking at it as a sacrifice or shame (Paragi 2017), proposal and report-writing functioned as return-gifts, although unrecognized as such. By returning stories of misfortune and pain in exchange for the gift of foreign aid, recipient NGOs offer the only valuable they have in a complex situation like the IsraeliPalestinian conflict: transparently documenting stories of the suffering of their beneficiaries. And while generating humanitarian knowledge is not without preliminaries in the region (Watenpaugh 2015), this unique return-gift strengthens and prolongs the relationship by constantly ensuring compassion or (ironic) solidarity on the donor side. It is a morally "heavy" return-gift, without which the recipient would be even more indebted to the donor. Documenting is not simply a technical matter of accountability, effectiveness, or trustworthiness. It is not the pain itself but being effective, transparent, and reliable in terms of documenting suffering that is essential for receiving contemporary gifts. 


\section{Conclusion}

The study aimed to contribute to a better understanding of the nature and "spiritual essence" of contemporary gift relations by exploring how Palestinian NGO recipients think about equality, compassion, solidarity, aid (in)effectiveness, conditions, and sacrifices. While the relationship was clearly seen as unequal between the donor and the recipient at the macro level, many of our respondents reported equality and partnership at an organizational level.

Reading the results in light of the theories on gift exchange highlighted the existence of nonfinancial return-gifts in contemporary aid relations. I did not aim for the "truth" but only aspired to conceptualize modern "ceremonies" in a critical way to see the extent to which aid can be understood as a reciprocated gift. Much else could have been explored, as noted by the interviewers upon reading a draft of this paper-for example, the complexity of relations between donors and recipients; the relation between aid and corruption; and the lack of progress in Gaza reconstruction after the war in 2014, a situation in which appeals were made, tragedies were drafted on paper, but the pledged money never arrived, at least according to Palestinian perceptions. It would also be great to extend the research by applying quantitative means and including more participants to see how representative the findings are. Still, the recent qualitative research generated new ideas - interpreting documentation of "stories of suffering" (part of the humanitarian and development knowledge) as return-gifts - that hopefully contribute to the literature and draw attention to the ambiguous nature of contemporary gift relations. It is the "spiritual essence" (embodied in the foreign aid gift), the existence of sacrifice (complying with political and technical conditions that ignore local norms, values, and identities), and return-gifts (sharing stories of suffering in written form and in a transparent manner) that makes foreign aid relations so complicated. As long as aid is provided in exchange for stories of suffering and alongside politically sensitive conditions that ignore the identities of the recipients, it cannot but further weaken the recipient society.

The "spiritual essence" of contemporary gifts seems to be more decisive than the matter of aid effectiveness, the latter of which can be measured only in comparison to the officially stated aid policy objectives. Economic effectiveness, the primary target of the so-called aid debate, cannot be separated from the broader context of social relationships. Development - as well as recovery from a humanitarian crisis - "has more to do with the strength of a country's institutions, the political and social systems that are developed through the interplay of a government and its people" (Deaton 2013:294). If we wish to explain the success or failure of foreign aid, we need to see what contemporary gift exchange means to the organizations and individuals involved in aid relationships and how it simultaneously strengthens the ambiguous solidarity between the donor and the recipient, creates rivalry between NGOs, and emphasizes division lines within the recipient society. Expecting organizations to share the misfortunes and pains of beneficiaries, to detail them in transparent ways for the sake of accountability and effectiveness, to tell their suffering to strangers who hardly know anything about their totality as human beings - purely for the sake of further aid - strengthens the validity of "ironic solidarity" (Chouliaraki 2013). The real irony, at least in the Palestinian case, is that these seem to be the best "marketable" goods that recipients, NGOs included, can offer to please their donors.

\section{Acknowledgments}

I thank my Palestinian colleagues, Hani E. and Akram A., and those that participated in the interviews for sharing their thoughts during the data-collection phase. I am also grateful for the anonymous reviewers' useful comments, for the feedback I received from Jon Pedersen during the revision, and for the kind and encouraging help provided by the editorial office. The content and conclusions of this paper are my sole responsibility. The research was supported by the European Union under a Marie Curie Intra-European Fellowship for Career Development grant (AIDINMENA project, 2013-2015 [2016], grant number PIEF-GA-2012-327088; host institute: Fafo Research Foundation, Oslo, Norway) and complemented by the Research Council of Norway.

\section{Comments}

\section{Annalisa Furia}

Department of Cultural Heritage, University of Bologna, Ravenna Campus, Via degli Ariani 1, 48121 Ravenna, Italy (annalisa.furia @unibo.it). 30 IX 16

\section{Power and Emotions: Some Remarks on Compassion and Solidarity}

Focusing on the effects of foreign aid on recipient organizations in the West Bank and Gaza Strip, Beáta Paragi's essay offers precious evidence of not only the ambiguous nature of foreign aid relationships as (g)local forms of political relations between donor and recipient states and nonstate actors but also the crucial role that emotions play in legitimating, keeping alive, and "ordering" such an ambiguous space. Openly and visibly productive in the foreign aid domain, the relation between power and emotions is, however, only partially acknowledged in Western political thought as politically significant, because it is mainly presumed to pertain to the rhetorical and/ or manipulative side of power dynamics and not really "to the core of the political" (Freeden 2013:9). Intrinsically connected to other constitutive, diverse, and complex relations — such as, just to mention the more immediate, those between culture and 
nature, rationality and animality, elites and masses, inclusion/ capacity and exclusion/incapacity, legitimation and consensus, and order and disorder - the link between power and emotions seems thus to have been granted, and for quite a long time, only a secondary status in political thought.

As convincingly argued by Martha Nussbaum (2013), starting at least with John Locke, Western liberal political thinkers, with few exceptions, have never placed much confidence in the role that emotions can play in the foundation and stability of liberal institutions. It is not only that emotions (as well as passions and desires) have been often regarded as mostly limited (and limiting), misguiding, and deprived of any valuable cognitive and evaluative content; they have also been mainly conceived of as expressions of morally and intellectually inferior impulses or instincts to be "civilized," disciplined, and somehow neutralized, whose open manifestation in the political domain is likely to be conducive to forms of manipulation, the violation of the sacred liberal principles of freedom and autonomy, the risk of fuelling conflicts, unpredictable forms of disorder, and ungovernable conducts.

While emotions have received different treatments within the context of other political doctrines-examples, in this sense, may range from the crucial role assigned to benevolence and sympathy by the Scottish Enlightenment thinkers and the acknowledgement of the importance of emotions in feminist thought to the role of altruism (and solidarity) in Hegel's ethical theory or in socialist doctrines and programs, of (patriotic) love in the republican tradition, and of pride and disdain in nationalist and conservative ideologies (Campello 2014; Freeden 2013) - it seems correct to say that, speaking in very broad terms, if liberal internationalists have left, and do leave, room for certain kinds of emotions (compassion, solidarity, and other "humanitarian" feelings) to be politically significant, most modern and contemporary liberal thinkers have disdainfully tended to cede, within the national borders and in the name of neutrality and respect of individual freedom, to antiliberal or nonliberal doctrines the invocation and shaping of emotions (but see Freeden 2013:7).

In the context of the recent so-called affective turn in contemporary political thought, an interesting exception, among others, is represented by the political role assigned to emotions by Martha Nussbaum. Starting from the conceptualization of emotions as forms of evaluative thought provided with a rich cognitive, intentional, and eudaimonistic content, Nussbaum $(2001,2013)$ affirms that the political cultivation of emotions is of crucial importance for liberal societies that aspire to justice and equal opportunity for all; that want their political culture, institutions, and values to be just and stable in moments of crisis; and that want their most demanding goals supported by adequately shaped public emotions, particularly those goals that require sacrifice and effort, such as social redistribution (welfare programs and tax systems), foreign aid, the defense of the state, the inclusion of the less advantaged, and the fight against racism, discrimination, and violence.
Against Kant's or Arendt's critical appraisal, Nussbaum argues that, within the context of a decent society, an emotion such as compassion, if adequately cultivated and supported by proper imaginative resources and skills, can be crucial to extend our moral interest to the other(s), to establish a bridge between our self-centred moral concerns and the moral concerns for and of others, and to decide to act in the name of solidarity against any form of injustice, dehumanizing treatment, and exclusion. According to Nussbaum, compassion can thus favor and be fully compatible with the respect of others' dignity, capabilities, and autonomy and the rejection of any form of victimization, a paternalistic approach, or humiliating, pietistic, and stereotyped representation.

On the contrary, Hannah Arendt, in her well-known writing on Humanity in Dark Times (which is included in Men in Dark Times; Arendt 1968 [1960]), strongly criticizes the French revolutionaries, because they attempted, through compassion, "to achieve solidarity with the unfortunate and the miserable" without understanding that this kind of humanitariansm "is not transmissible and cannot be easily acquired by those who do not belong among the pariahs." Even more disputably, they introduced into all modern revolutions the ruinous idea that one should attempt to "improve the lot of the unfortunate rather than to establish justice for all” (1986 [1960]:14).

Paragi's research clearly shows how the space opened by foreign aid is a space where compassion and solidarity are a constitutive part of a complex net of contract-like relationships where emotions are continuously "activated" and exchanged ("aid for pain, pain for aid") to reinforce rather than to progressively weaken the foreign aid relationship itself, to maintain (at multiple levels) the inclusion/exclusion divide, and to reinforce the (cultural, political, moral, "civilizational") distance between donors and recipients rather than to try to reduce it. It shows how important it is to investigate the specific nature and dynamics of foreign aid relationships, together with the humanitarian rhetoric, apparatus, and resources that support it, and how far we are from a real effort to "use" the invocation of compassion and solidarity to establish justice for all — how far we are from investing in the adequate cultivation of emotions, be they used inside or outside of our liberal, civilized countries.

\section{Tomohisa Hattori}

Department of Political Science, Lehman College, City University of New York, Bronx, New York 10468, and Master of Arts in Liberal Studies Program, Graduate Center, City University of New York, New York, New York 10016, USA (tomohisa.hattori@lehman.cuny .edu) 9 IX 16

It was Marcel Mauss himself who, reflecting on the casualties of World War I, first made the connection between his "archaic" theory of reciprocal gift exchange and the potential for "exchanging goods and persons" for conflict attenuation and solidarity in contemporary international relations - reciprocal 
cultural exchanges of renowned arts, scholars, sports teams, and others seem to be what he had in mind (1967 [1925]:8081,1990 [1925]:82-83). The primary scholar who sought to extend this insight to foreign aid, however, missed the fact that American technical assistance to France in the 1950s was essentially unreciprocated, hence outside of Mauss's conceptual framework (Dillon 1968). Pierre Bourdieu's (1977:5) notion of the misrecognized suspension of reciprocation for an uncertain period and Jonathan Parry's conception of a unilateral gift (1986) inspired my own reconceptualization of grant foreign aid as an unreciprocated giving practice symbolizing and naturalizing the material hierarchy that makes it possible (Hattori 2001).

Paragi's article disagrees with my reconceptualization of grant foreign aid. More specifically, she argues that, despite the lack of financial reciprocation, many of the documents provided by grant-receiving NGOs do indeed qualify as a reciprocal gift in Maussian terms, including grant applications, progress reports, post-project evaluations, and various films and videos documenting the project. On the basis of interviews with aid practitioners, she also argues that, because the decision-making process at project sites involved both donor and recipient aid workers, with the recipients sometimes fully in charge, the aid relationship was essentially an equal partnership.

There is a long history of efforts to distinguish the aid relationship from other areas of international relations, as indicated by the evolving terms used to describe it, from "development assistance" in the 1960s, to "development cooperation" in the 1970 s and 1980s, and to "development partnership" in the 1990s onward (e.g., Escobar 2011 [2004]). Scholars have also extended Clifford Geertz's (1985) interpretive approach to local knowledge to foreign aid practices, emphasizing the importance of local input into how aid projects work. Substituting both the discourse of "partnership" and the local knowledge about "partnership" for the reality involving a material hierarchy, however, is a classic example of what critical realist philosopher Roy Bhaskar (1998 [1979]:132-140) has called the "epistemic fallacy" (i.e., the misrecognition of what people feel, think, say, or write for what really exists). To put this another way, by interpreting these documents (which form part of preconditions for receiving grant aid) "as if" they were return-gifts, Paragi effectively regards aid workers and their organizations "as if" they were equal partners whose moral agency is not affected by the absence of material reciprocation (on the contrary point, see Hattori 2003b:161). This raises a political question of knowledge production: whose end does Paragi's interpretation serve?

In order to sustain her assertion that an equal partnership exists in this case, Paragi must provide a much more careful specification of what the relationship between donor and recipient actually entails and how specifically it is able to overcome the very real material hierarchy of political and economic power in which it is situated (on this kind of explanatory critique, see Collier 1994:169-205). Past studies (e.g., Ostrander 1993) suggest that a critical condition of equality is the willingness of the donors not only to relinquish control over project design, im- plementation, and evaluation to the recipients but also to allow them to share in funding decisions. The donor-recipient relationship Paragi studied does not seem to have met this standard.

\section{Nora Lester Murad}

Aid Watch Palestine and Dalia Association, Jerusalem, Palestine (noralestermurad@gmail.com).31 VIII 16

Writing about international aid using the framework of "contemporary gifts," Beáta Paragi breaks ranks with both technical and political analysts of aid and suggests that anthropology may offer insight previously hidden. Her deep investigation into Palestinian "recipient" opinions brings nuance and depth to the discussion, but given how politicized and damaging aid can be in Palestine, civil society aid critics like me will bristle at the contention that aid is a gift.

Paragi and her team interview Palestinian recipients of aid and cite their statements about partnership, concluding that aid does evoke concepts of solidarity, equality, and reciprocity. Her assertion is that recipients of aid "return" a gift in the form of documentation of stories of suffering which, she says, leads to the constant circulation of the "gift."

Paragi considers other possibilities, but ultimately decides, "It is the obscure difference between gift and exchange embodied in the concepts of reciprocity and sacrifice . . . complemented with the 'subtle balance of dependence and independence causing power and control to be deeply ingrained,' (Komter 2005:70), that will explain the unintended consequences of foreign aid." The alternative paradigm is that inequality is not an unintended consequence of well-intentioned international aid but rather the intended consequence of selfinterested neoliberal and neocolonial manipulation in the guise of aid.

The gift logic only works if one believes that international aid is motivated by compassion and social responsibility. But even if there is a compassionate intention motivating international aid, it is not clear how or why that compassionate intention would extend beyond the original "giver" (presumably the taxpayer, who is the source of funds for overseas development assistance) to motivate the professional aid actor. The professional aid actor uses professional discretion to allocate funds but is not the source of funds, and it is not clear what she or he has "sacrificed" to provide the gift.

On the other hand, if aid was strictly self-interested and harmful in its impact, we would need another way to explain the many positive relationships with international aid actors that Palestinians talked about in Paragi's interviews. Focusing on the role of power and coercion may shed light. Coercion can be at play even if aid actors do not explicitly use funding as a stick or carrot (which they sometimes do). For example, power can be used a priori to limit aid choices (e.g., amounts, modalities, and terms and conditions) from which civil society actors then "freely" choose. On a deeper level, power can be 
used to shape macro-level social, political, and economic forces within which civil society actors define themselves and articulate their interests. Paragi's informants may perceive their relationships with aid actors as partnerships, because those who accept aid are those who have been influenced to perceive aid in a positive manner.

Terms used by recipients show evidence of this type of invisible coercion. Paragi says, "Concepts such as 'professionalism,' 'credibility,' 'local knowledge,' 'transparency,' or 'commitment' were widely applied to describe a 'true partnership' by recipient NGOs." She goes on to say, "Typical to this relationship is the recipient's ability to 'propose the project,' 'to assess what is needed in a certain project,' and 'to feel [that] we are one team' or 'we work as one family'." Yet these are not terms that Palestinians generally use when referring to their own interests and priorities. Why did Paragi's informants not say that "true partnership" is based on common commitment to selfdetermination, international law, political support, and human rights? It may be because the aid relationship is already preconstituted in apolitical terms, and the recipients do not expect much beyond grant money. They may have already conceded to work within the agenda set by donors and therefore do not seek to challenge it within the confines of a funded project.

It is also possible that personalization of aid relationships strengthens the ability to perceive aid in gift terms. Paragi says many Palestinian NGO leaders "experienced equality and considered themselves 'full partners,' being able to influence donor policies and priorities." To the extent that givers or receivers perceive their interpersonal interactions as constituting the organizational relationship, they may be distorting reality. Even if one recipient influences one individual international aid actor, there is not likely to be an automatic change of policy at the organizational level.

Analysis at the interpersonal level may hide rather than expose political dynamics. In discussing the relationship between giver and receiver, Paragi seems to prioritize social cohesion over self-determination. However, social cohesion can grow as much from dependence and inequality as from freedom. Are Palestinian informants talking about their goals for their interpersonal relationships or their goals for their people? It is my experience that professionalized aid usually interferes with the potential for reciprocity inherent in true philanthropy or solidarity. Givers and receivers relating on the basis of shared interests, rather than on the value of an exchange, builds community, which is transformational.

In conclusion, while I find Paragi's study to be an important contribution to understanding the micropolitics of relationships, I find myself resistant to her conclusion that aid in Palestine can be usefully analyzed in terms of gifts. Perhaps it is my naive or idealistic view that the value of a gift should be determined by its value to the recipient, not its value to the giver. If aid actors wanted to give valuable gifts, they would "give" assistance to end the conditions that create the need for aid in the first place. While there are certainly aid actors who work toward this objective, and while there are certainly are true partnerships between some
Palestinians and international aid actors, I suspect these are a rare few. In these cases, I suspect that aid funds are probably tangential to the relationship rather than definitive.

Paragi says that international aid leads to a continuous "exchange" of "aid for pain." If that is sufficient to deem aid a gift, then it may be time to change the way we use the term.

\section{Sahar Taghdisi Rad}

Department of European and International Studies, King's College London, 22 Kingsway, London, United Kingdom (st54@soas.ac.uk). 8 IX 16

There are few political economy relations between national and international agents that are characterized by more exploitative dynamics than those instigated by international aid. Paragi's analysis of NGOs' reciprocation of the "contemporary gift" of aid, although providing some insights into the analysis of humanitarian aid, leaves a number of important gaps in its application to development assistance. This comment focuses on the paper's analytical shortcomings in two areas: first, the relevance of the application of Mauss's gift exchange framework to the analysis of development aid, particularly in the context of one of the most long-lasting conflicts in the world; and second, the author's implicit treatment of NGOs as an inherent and unquestioning component of the "recipient" entity.

The article treats the "benevolent gift" of aid as stemming from "social relations" of "solidarity [and] compassion with the less fortunate within the international community," while arguing that, despite the "good" intentions, aid could have some "ambiguities and unintended consequences." Paragi's assumption that aid is inherently "good" and aimed at helping the "less fortunate" parts of the world is at best optimistic and at worst dismissive of the widely documented hazardous history of foreign aid since its inception. The post-Second World War Marshal Plan introduced aid as an instrument of not only gathering allies against the "enemy" but also ensuring that those allies are economically strong partners. In the words of President Kennedy in 1961, "foreign aid is a method by which the United States maintains a position of influence and control around the world, and sustains a good many countries which would definitely collapse, or pass into the Communist bloc" (Hayter 1971:5).

The increasing focus on aid to developing countries since the 1970s has carried forward even more intense power dynamics, aimed at maintaining the global hegemony of former imperial powers. As Teresa Hayter states in her seminal work Aid as Imperialism, based on extensive research into Latin America, "aid can be regarded as a concession by the imperialist powers to enable them to continue their exploitation of the semi-colonial countries .... [It] increases the likelihood that the governments of Third World countries will tolerate the continuation of massive outflows of private profits and interest on past debt. It may 
also help to create and sustain ... a class which is dependent on the continued existence of aid and foreign private investment and which therefore becomes an ally of imperialism" (1971:9). The donors' continued financing of the Palestinian National Authority since its creation mirrors this rhetoric (Khalidi and Samour 2011).

The significance of aid as a foreign relations tool intensifies even more in the context of conflict zones, such as the occupied Palestinian territories. Although here peace-building efforts and conflict resolution initially masked donors' deeper interests in keeping a stake in the conflict, this should not lead one to take as a starting point of analysis an assumption of aid as an originally "benevolent gift." As Anderson (1999:1) puts it, "when international assistance is given in the context of a violent conflict, it becomes a part of that context and thus also of the conflict." The World Bank's 1993 Investment in Peace set out the shape and direction of a future Palestinian state and economy even before the Oslo Accords were finalized, signalling donors' direct involvement in the conflict and its aftermath.

In this context, an emphasis on the concept of "reciprocity" is also questionable. The political objectives of foreign aid are already fulfilled the moment aid is disbursed, as the recipient's dependency on and subsequent submission to the donor is at once established. Fulfilling any form of donor requirement and conditionality, what Paragi calls "reciprocation" then serves a specific purpose. Assessment of recipients' use of aid has not been a major concern for many donors until recently - explaining the establishment of donor agencies' evaluation departments only in the late 1990s. In response to the 1990s aid fatigue, donors pointed fingers at the recipients by imposing a number of conditions to improve transparency and accountability. Such bureaucratic box-ticking requirements, which were also imposed on recipients of structural adjustment programs during the same period, put additional pressure on the recipients' already weak administrative capacity with little positive impact on aid effectiveness. As such, Paragi's analysis of the NGOs' reciprocity responses through "documenting suffering" could perhaps explain some of the dynamics facing NGOs in the humanitarian sector but is of limited application to development assistance. Today, it is in fact a "positive" language of "empowerment," "good governance," and "equality" that wins the recipients more aid in the context of aid fatigue.

Paragi's analysis could also benefit from the broader critical discourses on the nature of NGOs and their relationship with the state and external actors. While recognizing the change in the nature of Palestinian NGOs after the Oslo Accords, Paragi still treats them as a homogenous component of what constitutes the "recipient." Contrary to the classical notion of the civil society, the post-Oslo aid-dependent Palestinian NGO body has, with exceptions, been seen as bound to the state power and donor apparatus by ties of cooperation rather than opposition. From a Gramscian perspective, the civil society, defined more broadly than NGOs per se, is closely linked to the "political society": while the state uses coercion, the civil society creates consent with the ongoing hegemonic order. As such, the civil society, with NGOs as a component of it, cannot be analyzed distinctly from the state and the donors. In Palestine, this "NGOization" is believed to have contributed to the transformation of the national agenda from a struggle for self-determination and sovereignty to a particular and limited set of technical issues concerning peace building, conflict resolution, and other issues related to donor funding interest. Through activities that emphasize the individual over the community, the NGOs have at times contributed to the fragmentation of the Palestinian society while nurturing "globalized Palestinian elites" (Hanafi and Tabar 2002) in support of donor agendas and the peace process and distant from local stakeholders and radical politics.

\section{Alaa Tartir}

Centre on Conflict, Development, and Peacebuilding, Institut de Hautes Études Internationales et du Développement, 1211 Geneva 1, Switzerland (alaa.tartir@graduateinstitute.ch). 25 IX 16

\section{International Aid to Palestinians: A Cursed Gift}

Over $\$ 30$ billion has been spent since 1993 by international donors as aid for Palestinians living in the occupied West Bank and Gaza Strip (OECD 2016). This "investment" in peace and development has made Palestinians one of the highest per capita recipients of nonmilitary aid in the world. In spite of those sums, however, peace and development remain elusive, and this aid has failed to achieve its three main objectives: lasting peace, effective and accountable Palestinian institutions, and sustainable socioeconomic development. Instead, Palestinians are forced to live in an aid-development paradox: increased amounts of aid are associated with major declines in socioeconomic and development indicators.

This aid has failed the Palestinian people miserably. It has failed to make them feel more secure, it has failed to reverse the cycles of de-development, it has entrenched the status of a captive Palestinian economy that is unproductive and aidreliant, it has created structural deficiencies in the governance realm, and it has sustained and subsidized the Israeli military occupation. It also sustains the Palestinian National Authority (PNA), which is a heavy burden on the Palestinian people, and has resulted in major negative transformations in the Palestinian civil society, creating an "NGO republic" in the West Bank and Gaza Strip. Around 10\% of aid is received by the highly aid-reliant Palestinian NGOs (DeVoir and Tartir 2009).

These established arguments and conclusions in the critical literature on the political economy of aid in Palestine perceive "aid-as-a-gift" as a problematic notion and as an idea full of tensions and contradictions. The burden of that "gift" (aid) is 
much bigger (in terms of social, economic, and political consequences and ramifications) than the gift itself, and therefore it is a twice-cursed gift: it curses the giver and the receiver.

The mere "giving" of aid within the existing framework cannot be a sign of "strong international solidarity." The aid industry is not an innocent one; it results in effective "reversed solidarity" with destructive consequences. Arguably, understanding aid within the framework of theories of gift exchange undermines other key understandings, such as aidas-right and aid-as-obligation. A gift exchange model also assumes the existence of two actors in the process of giving, the donor and the recipient. However, in the case of Palestine, the ultimate beneficiary of this aid is a third actor (the Israeli occupier) who is not sufficiently considered by the gift exchange model. Research shows that a considerable portion of aid to Palestinians (which could reach up to 78\%; Hever 2015) is redirected to Israel's economy. In this case, aid to Palestinians, within the existing aid industry configurations as designed by the World Bank more than two decades ago, is a generous gift to Israel, its military occupation, and its illegal colonies/settlement expansion project and is a pure curse to the Palestinians.

Yet, the Palestinian actors, either governmental or nongovernmental bodies, are not able or willing to exit the harmful aid game. And they therefore become part of the problem by accepting, happily in most cases, the cursed gift instead of confronting the conditionality attached with this gift and challenging its assumptions, objectives, delivery, allocation, and indeed the overall framework of giving. This aid-curse could be gradually reversed; however, the vested interests of the political and NGO elite whom the aid industry has created are blocking any meaningful and fundamental reform to the failed Oslo aid model (in addition to the similar role resumed by the donors, as Dr. Jeremy Wildeman and I have reported and argued in multiple articles; Wildeman and Tartir 2013, 2014). This can be testified to by some of the NGO voices, as reported by Dr. Paragi, who argued that they dictate and lead the aid-giving process and refuse the donors conditionality. There is ample evidence that suggests the implausibility of such self-serving voices, as they dismiss the failing patterns of aid and the miserable realities on the ground. Such voices are instead occupied by technical reporting to the donors and by the creation of different forms of pegging as tools for fundraising.

Indeed, not all Palestinian NGO and civil society actors can be put in one basket, because there are genuine success stories. But it is safe to argue that the micro successes proclaimed by the majority of NGOs and their donors, as testified to by their reports, newsletters, videos, and social media pages, are ironic if not surreal, when contrasted with the macro-mega failures (e.g., the failure of aid to reconstruct Gaza, or the entrenchment of the intra-Palestinian divide and fragmentation, or the failure to reverse the cycles of de-development and defeat dependency). The macro-micro paradox of the aid industry in Palestine explains the continued existence of failing processes: the majority of actors (recipients and donors) are always busy with their operational and bureaucratic processes while eagerly dismissing the overall picture that they are unable or unwilling to change.

Finally, the role of emotions in the process of aid giving and receiving is far from straightforward. The Israeli colonization of Palestine is not a humanitarian crisis that evokes a sense of compassion and pity in aid actors. The destruction of Gaza is not a natural disaster but a man-made one, and poverty in Palestine is politically constructed. Therefore, the aid ineffectiveness is not due to technical failures or to the failure of transforming the emotions of the well-intended aid workers into actions. Feeling "sorry" for the Palestinians but being unable and in most cases unwilling to challenge the power dynamics and to confront the damaging status quo of the aid industry and military occupation adds another layer to the cursed aid model, as the politics of emotions can be used as remedy for the feeling of guilt. Certainly, this is not to argue that the individual aid workers are necessarily doing harm, but this is to argue that the collective emotions and actions of aid workers (and their subordinate aid recipients) are dictated by rigid, self-enforcing, and self-serving aid structures and inappropriate frameworks that are doing harm by denying the right of the Palestinians to development and selfdetermination.

Dr. Beáta Paragi's contribution reveals some of the key complex dynamics that feature in the aid industry in Palestine and operationalizes dimensions related to "contemporary gifts" from the NGO perspective. The vicious cycle ("aid for pain, pain for aid") will continue to do harm, as discussed by Dr. Paragi, until the failed Oslo aid model is laid to rest.

\section{Reply}

In this article, I argue that, if foreign aid can be conceptualized within the analytical framework of gift exchange theories, then return-gifts deserve to be acknowledged and identified. I have received five comments. Let me reply to them in the following way.

Annalisa Furia focuses on the role played by politically relevant emotions (e.g., compassion, solidarity, pity, and fear). Citing two conflicting views-Martha Nussbaum saying "the political cultivation of emotions is of crucial importance for liberal societies that aspire to [achieve] justice and equal opportunity for all" and emphasizing that "compassion can [thus] favour, and be fully compatible with, the respect of others' dignity, capabilities and autonomy" and Hanna Arendt arguing that the French revolutionists introduced "the ruinous idea that one should attempt to "improve the lot of the unfortunate rather than to establish justice for all'"-Dr. Furia draws attention to the contested and ambiguous role of emotions. Her reading of 
my article, that "compassion and solidarity are a constitutive part of a complex net of contract-like relationships," is very much in line with findings indicating the instrumental role emotions play in raising awareness and strengthening solidarity between people living geographically far away.

Objections formulated by Nora Murad and Sahar Taghdisi Rad are closely linked to the contested role of emotions. In their reading, "the gift logic only works if one believes that international aid is motivated by compassion and social responsibility," and I assume "that aid is inherently good and aimed at helping the 'less fortunate' parts of the world [which] is at best optimistic and at worst dismissive of the widely documented hazardous history of foreign aid since its inception." It is true that I do not provide any detailed account of the failures of the foreign-aid regime. Neither do I believe, however, that my argument would have required it (as I made a reference to Furia 2015, among others). I did not claim that foreign aid or the regime behind it has ever been good, but I doubt whether development (humanitarian) cooperation can be understood, or judged, without acknowledging the intentions, sentiments, and emotions on the donor side (or on the recipient side, for that matter). Western donor countries are democracies, and as such, they cannot ignore their public opinion. If the solidarity motive (in general, the role of emotions) is irrelevant in aid relations, how do recipients claim to campaign for more foreign aid? ${ }^{17}$

Various Eurobarometer surveys document clearly that most Europeans do believe in the positive role played by foreign aid in international relations, which cannot be ignored by donors as political powers (Eurobarometer 2005, 2007, 2010, 2011, 2013). A large majority of respondents in Europe say it is important or very important to help people in developing countries (average $89 \%$; Eurobarometer 2015). There is no reason to assume that the Palestinian case would be an exception. In $2015,76 \%$ of respondents were convinced that aid for developing countries contributes to a more peaceful and equal world, whereas $74 \%$ agreed that tackling poverty in developing countries is a moral obligation for the EU (Eurobarometer 2015). Not only Western "neoliberal" powers (donor governments), but the general European - and American, for that matter - public seems to have grown used to the notion that "they can shape and control most aspects of power and policy across the Arab world, whether due to imperial self-interest, energy requirements, economic needs, or pro-Israeli biases" (Khouri 2011). Indeed, as indicated by the Eurobarometer surveys, most of the Europeans are ready to provide help for the developing world, the Middle East included, even if they do not know precisely the scope or magnitude of the problem to be solved (as public opinion polls are not school exams).

17. The Arab Barometer (2014) survey indicates a high rate of support for foreign aid in general. Focusing on Egypt, Jordan, and Palestine (Lebanon and Iraq may serve as a comparison), an overwhelming majority would support a further increase in foreign aid (Egypt: 83.8\%; Jordan: 78.7\%; Palestine: $83.5 \%$ ), even if half of the population (at least) simultaneously express discontent with it. See Arab Barometer Wave III, q701, question on the future of foreign aid.
Contemporary international solidarity, even if only compassionbased, self-serving, or ironic, is so closely linked to the concept of global justice that it is the sense of injustice - for example the Palestinian pain in Gaza or the West Bank-combined with the spectacle of suffering (Chouliaraki 2013) that mobilizes Western and regional public support for official foreign aid and private charities in donor countries; they complement the official foreign policy interests. This mobilization - and here I agree with the reviewers - does not mean that international solidarity (in form of aid) can buy justice and truth in the recipient country. ${ }^{18}$

Following Mauss, many-Sahlins (1972), Alan D. Schrift (1997), and Marcel Hénaff (2010a)—claimed that giving is mostly of a positive nature: relationships established by the gift guarantee the core of any social bond. In other words, "to give is to recognize in order to be recognized" (Hénaff 2010a). However, analyzing the practice and forms of gift-giving between individuals, the American philosopher Michael Sandel argued that money, including monetized or in-kind gifts, cannot buy friendship and function, at most, as tokens and expressions of friendship. Converting gestures or gifts into commodities does not destroy them altogether, Sandel argues, but it apparently diminishes their value. Money or gifts - aid for that matter-cannot buy friends, since true friendship and the related social practices that sustain friendship are constituted by shared norms, attitudes, and virtues. ${ }^{19}$ Commodifying these practices is possible, but it displaces essential norms - sympathy, solidarity, generosity, and thoughtfulness - by replacing them with market values. To sum up Sandel's argument, if money can buy friendship, it can do it only in a degraded form (Sandel 2011:107). The history of aid (money) and the contested relations between donors and recipients prove that this conclusion applies not only at the micro level but also to organizationallevel cooperation between NGOs and to official aid relations at the macro level (between governments).

By discussing the existence of "reciprocity" and "return-gifts" (admittedly, only at the NGO level), I intended to draw attention to the irony embodied in the relations between recipients and their donors. I agree with Taghdisi Rad that "the civil society, or NGOs in this context, cannot be analyzed distinctly from the state and the donors." Their activities, however, complement and serve the official and macro-level policies (politics) not only according to Gramsci but by the very definition of ODA. Most civil recipients cannot but comply with the technical conditions formulated by their donors (e.g., responding to calls, writing proposals and appeals, making final reports, and guiding evaluation committees). They cannot but accept the rules of the game formulated at higher levels. Transparency and accountability do not simply serve aid effective-

18. On the hegemony of contemporary solidarity, see a sister article based on the same data set and published in Alternatives: Global, Local, and Political (Paragi 2016b).

19. It applies to relations explored by political science and international relations too. 
ness (Furia 2015) but allow the donors to know and control their recipients too. By participation, people working at local civil society organizations often find themselves caught between their own history, culture, and society on the one hand and the externally defined donor priorities and values on the other hand (Andersen 2012; Contu and Girei 2014; Khan, Westwood, and Boje 2011).

Hattori's critique centers around the concept of "unilateral” gifts, emphasizing that "Pierre Bourdieu's (1977:5) notion of the misrecognized suspension of reciprocation for an uncertain period and Jonathan Parry's conception of a unilateral gift (1986) inspired [his] own reconceptualization of grant foreign aid as an unreciprocated giving practice symbolizing and naturalizing the material hierarchy that makes it possible (Hattori 2001)." Stressing that foreign aid (grants) is not only financially unreciprocated but also unreciprocated in any other (nonmaterial) terms, Hattori further argues - in a similar way to Nora Murad, who says that "inequality is not an unintended consequence of well-intentioned international aid but rather the intended consequence of self-interested neoliberal and neocolonial manipulation in the guise of aid" - that I fail to address the question of (in)equality by identifying return-gifts, that is, by "interpreting these documents (which form part of preconditions for receiving grant aid) 'as if' they were return-gifts" and effectively regarding "aid workers and their organizations 'as if' they were equal partners." I do not think that this reflects what I wrote. My article has been about perceptions - about how people working at various Palestinian aid recipient organizations think about their cooperation with their donors. Some of them reported equality, others emphasized its lack. A careful reading of the article makes clear the distinctions between respondents' experiences and my interpretation, on the one hand, and the experiences reported at the micro level and the reality of the macro level, on the other hand. It must also be emphasized that reciprocity does not necessarily imply the strict equivalence of benefits. While "rough equivalence" is the usual expectation "among equals," reciprocity can also characterize relations among unequals in international relations (Keohane 1986) both at the macro and meso/micro levels.

My main problem with the unilateral or unreciprocated interpretation of donor money concerns (the lack of) recognition. If reciprocity is denied and if (symbolic, nonmaterial) return-gifts are neither recognized nor acknowledged, the recipient, the recipient's identity, and the entire relationship become somehow inferior. It implies, on the one hand, that donors give for pure pleasure, for fun, and for "symbolic domination"-indeed, that is, that donors give in order to take something that would otherwise not be given by the recipient. On the other hand, the time and energy, all of the (otherwise scarce) resources invested by the recipients into any aid project (from proposal writing through implementation to reporting), become secondary-along with the substance: their misfortune, pain, underdevelopment, and the lived reality of injustice.
Gifts (foreign grants) are invited by the pure existence of a person living in poverty and suffering injustice. As Georg Simmel argued long ago, "poverty is relational and it is assistance which creates the poor"-in order to prevent him from revolting (Simmel 1965:138). This is what Michael Duffield called "'the riot control' end of a spectrum encompassing a broad range of global poor relief" in the context of contemporary foreign aid (Duffield 2001:9). But how can the "poor" or the "sufferer" return the gift? In the very moment when money, gifts, or in-kind assistance is offered with the promise of cure (e.g., eliminating poverty and alleviating suffering), images, stories, and other documentation of misfortune may become a commodity, an object to be exchanged. Without the marketable story - without images, reports, documents, appeals, and proposals, without discourse on poverty, underdevelopment, and suffering - there is no money. The contemporary history of foreign aid proves it beyond any doubt. As argued by Chris Gregory (1982:100-101), “Commodity exchange is an exchange of alienable objects between people who are in a state of reciprocal independence that establishes a quantitative relationship between the objects exchanged . . . Gift exchange [however] is an exchange of inalienable objects between people who are in a state of reciprocal dependence that establishes a qualitative relationship." Donor money (aid) is of alienable nature; the return-gift (the experience of suffering and pain) is not. Documenting and documents, however, turn them into "inalienable" objects to be delivered to the donor.

It is even more sad, even ironic, that segments of recipient societies are forced to compete for donor money. Indeed, it is not simply "pain" (as an inalienable object) that matters, but how it is sold: the better a story is documented and marketed, the more attention and money is generated. If it sounds outrageous, the alternative interpretation is not at all more favorable. In the absence of material or symbolic reciprocity, the gift-relation is not about exchange (as Mauss and his followers maintain), and it has nothing to do with solidarity, either; rather, the opposite is the case. Invented and explored by Michel Serres (1982), it is the concept of the parasite that describes the relations when the receiver is "always taking, never giving" (cited by Pyyhtinen 2014:12, 67). The parasite takes advantage of its relationship with the giver/donor without being able or willing to contribute to the social order by reciprocity. If the current order of international relations, international development cooperation included, is based on nonreciprocity (as Hattori maintains), foreign aid cannot but produce international parasites. The only way to escape this conclusion is to acknowledge the existence of return-gifts, however ironic that sounds.

If Mauss claimed that there is a magical force included in the given thing, Marcel Hénaff argued that the implication of the donor in the given thing involves "a transfer of soul and of substantial presence" and "the entire network of gift exchange" is constructed of the fact "that everyone must place something of himself at risk outside of his own place and receive something from others within its own space" (Henaff 2010a:126). 
The "soul" of contemporary aid-the existence of which is acknowledged not only by the Palestinians who were interviewed but by the reviews of the original article itself (by Tartir, Taghdisi Rad, and Murad)—makes it possible to interpret aid within the "gift exchange" framework. If recipients are forced to absorb "abstract" neoliberal ideas (alongside with their much less abstract, practical consequences) as part of the aid package (Nakheh 2013; Tabar 2015; Tartir 2014), donors may also receive stories of misfortune (poverty, pain) in the form of documents as return-gifts.

I am grateful for the comments. Even if I could not reply to all of the remarks, I have learned a lot by reading them. I have only one final thought regarding Hattori's question on the politics of knowledge production. Although I received funding from the EU and Norway, my research was not a commissioned research project. I simply made interviews and interpreted the data without anyone telling me what to think or what to write. Hattori's question is interesting and a bit provocative, if not cynical (if I seem to be a bit too sensitive here, that is because I have a Hungarian passport and the subject of the paper concerned the Israeli-Palestinian conflict). These sorts of questions are quite popular in certain parts of the world-take Russia, Israel, Egypt, and Hungary, for example (Economist 2014). It may be only a matter of time until not only civil society activists but also researchers in the academic sector will also be asked to keep their distance from anything that might be of a political nature if they accept "foreign" funding. ${ }^{20}$ To sum up, I hope the article itself and my reply give an adequate answer to Hattori's question.

-Beáta Paragi

\section{References Cited}

Anderson, Mary B. 1999. Do no harm: how aid can support peace or war. Boulder, CO: Rienner. [STR]

- 2012. Time to listen: hearing people on the receiving end of international aid. Cambridge, MA: CDA Collaborative Learning Projects.

Anheier, Helmut. 2014. Nonprofit organizations: theory, management, policy. New York: Routledge.

Arab Barometer. 2014. Public opinion survey, wave III, 2012-2014. http:// www.arabbarometer.org/.

Arendt, Hannah. 1968 [1960]. Men in dark times. New York: Harcourt, Brace \& World. [AF]

- 1990 [1963]. On revolution. London: Penguin.

Arndt, Channing, Sam Jones, and Finn Tarp. 2010. Aid, growth, and development. UNU-Wider Working Paper 96/2010. https://www.wider.unu.edu /sites/default/files/wp2010-96.pdf.

Baldwin, David A. 1985. Economic statecraft. Princeton, NJ: Princeton University Press.

Beale, Stéphane J. 2013. The ethics of new development economics: is the experimental approach to development economics morally wrong? Journal of Philosophical Economics 7(1):2-42.

Bhaskar, Roy. 1998 [1979]. The possibility of naturalism: a philosophical critique of the contemporary human sciences. 3rd ed. New York: Routlege. [TH]

Blau, Peter M., ed. 2003 (1964). Exchange and power in social life. New York: Wiley.

20. Acknowledging that Hattori's perspective is not identical to that of the Hungarian government, a remark is needed here: my reply had been written before the Central European University story in Hungary raised worldwide concerns. See, for example, Rankin 2017.
Bourdieu, Pierre. 1977. Outline of a theory of practice. New York: Cambridge University Press. [TH]

Bouris, Dimitris. 2014. The European Union and Occupied Palestinian Territories: state-building without a state. London: Routledge.

Boyce, James K. 2002. Investing in peace: aid and conditionality after civil wars. Adelphi Paper No. 351. Oxford: Oxford University Press.

Bruni, Luigino, and Stefano Zamagni, eds. 2013. Handbook on the economics of philanthropy, reciprocity and social enterprise. Northampton, MA: Elgar.

Brynen, Rex. 2000. A very political economy, peacebuilding and foreign aid in the West Bank and Gaza. Washington, DC: US Institute of Peace.

Camenisch, Paul F. 1981. Gift and gratitude in ethics. Journal of Religious Ethics 9(1):1-34.

Campello, F. 2014. Freedom and solidarity: some remarks in the light of the contemporary reception of Hegel. ethic@: an international journal of moral philosophy 13(1):175-187. [AF]

Carapico, Sheila. 2014. Political aid and Arab activism: democracy promotion, justice and representation. New York: Cambridge University Press.

Chouliaraki, Lilie. 2013. The ironic spectator: solidarity in the age of posthumanitarianism. London: Cambridge University Press.

Collier, Andrew. 1994. Critical realism: an introduction to Roy Bhaskar's philosophy. New York: Verso. [TH]

Contu, Alessia, and Emanuela Girei. 2014. NGOs management and the value of 'partnerships' for equality in international development: what's in a name? Human Relations 67(2):205-232.

Corbin, Juliet A., and Anselm Strauss. 2008 (1991). Basics of qualitative research: techniques and procedures for developing grounded theory. Thousand Oaks, CA: Sage.

Custer, Samantha, Z. Rice, T. Masaki, R. Latourell, and B. Parks. 2015. Listening to leaders: which development partners do they prefer and why? Williamsburg, VA: AidData.

Dana, Tariq. 2013. Palestinian society: what went wrong? Ramallah, West Bank: Al Shabaka.

Deaton, Angus. 2013. The great escape: health, wealth, and the origins of in equality. Princeton, NJ: Princeton University Press.

Derrida, Jacques. 1994 (1992). Given time. Chicago: University of Chicago Press. DeVoir, J., and A. Tartir. 2009. Tracking external donor funding to Palestinian non-governmental organizations in the West Bank and Gaza 1999-2008. Jerusalem, Israel: Palestine Economic Policy Research Institute and NGO Development Center. https://goo.gl/dloqxl. [AT]

Dillon, Wilton S. 1968. Gifts and nations: the obligation to give, receive, and repay. The Hague, Netherlands: Mouton. [TH]

Duffield, Mark. 2001. Global governance and the new wars, the merging of development and security. London: Zed.

Easterly, William. 2006. The white man's burden. New York: Penguin.

European Commission. 2014. Evaluation of the European Union's cooperation with the occupied Palestinian territory and support to the Palestinian people 2008-2013. Brussels, Belgium: European Commission.

Economist. 2014. Donors: keep out. Economist, September 12.

Emerson, Richard M. 1976. Social exchange theory. Annual Review of Sociology 2:335-362.

Endresen, Lena C. 2001. Contact and cooperation: the Israeli-Palestinian peopleto-people program. Oslo, Norway: Fafo Institute for Applied Sciences. http:// www.fafo.no/images/pub/2001/659.pdf.

Escobar, Arturo. 2011 (2004). Encountering development: the making and unmaking of the Third World. Princeton, NJ: Princeton University Press.

Eurobarometer. 2005. Attitudes towards development aid. Special Eurobarometer 222. Brussels, Belgium: European Commission.

. 2007. Europeans and development aid. Special Eurobarometer 280 Brussels, Belgium: European Commission.

. 2010. European development aid and the Millennium Development Goals. Special Eurobarometer 352. Brussels, Belgium: European Commission. 2011. Making a difference in the world Special Eurobarometer 375. Brussels, Belgium: European Commission.

- 2013. EU development aid and the Millennium Development Goals Special Eurobarometer 405. Brussels, Belgium: European Commission.

2015. The European Year for Development: citizens' views on development, cooperation and aid. Special Eurobarometer 441. Brussels, Belgium: European Commission.

Eyben, Rosalind. 2005. Donors' learning difficulties: results, relationships and responsibilities. IDS Bulletin 36(3):98-107.

- 2006a. The power of the gift and the new aid modalities. IDS Bulletin 37(6):88-98.

, ed. 2006b. Relationships for aid. London: Earthscan. 
Fechter, Anne-Meike. 2014. The personal and the professional in aid work. London: Routledge.

Ferguson, James. 1990. The anti-politics machine: development, depoliticization and bureaucratic power in Lesotho. Minneapolis: University of Minnesota Press.

Freeden, M. 2013. Editorial: emotions, ideology and politics. Lournal of Political Ideologies 18(1):1-10. [AF]

Furia, Annalisa. 2015. The foreign aid regime: gift-giving, states and global dis/ order. London: Palgrave Pilot.

Geertz, Clifford. 1985. Local knowledge: further essays in interpretive anthropology. New York: Basic. [TH]

Glaser, Barney G., and Anselm L. Strauss. 1967. The discovery of grounded theory: strategies for qualitative research. Chicago: Aldine.

Goldspink, Chris, and Robert Kay. 2004. Bridging the micro-macro divide: a new basis for social science. Human Relations 57(5):597-618.

Gouldner, Alvin W. 1960. The norm of reciprocity, a preliminary statement. American Sociological Review 25(2):161-178.

Gregory, Christopher. 1982. Gifts and commodities. London: Academic Press.

Guérin, Isabelle. 2014. Juggling with debt, social ties, and values: the everyday use of microcredit in rural South India. Current Anthropology 55(S9):S40S50.

Gulrajani, Nilima. 2011. Transcending the great foreign aid debate: managerialism, radicalism and the search for aid effectiveness. Third World Quarterly 32(2):199-216.

Hanafi, S., and L. Tabar. 2002. The emergence of a Palestinian globalized elite: donors, international organizations and local NGOs. Journal of Refugee Studies 20(1):154-156. [STR]

Hattori, Tomohisa. 2001. Reconceptualizing foreign aid. Review of International Political Economy 8(4):633-660.

. 2003a. The moral politics of foreign aid. Review of International Studies 29(2):229-247.

. 2003b. Gift as a mechanism of consent: international aid organizations and the ethical hegemony of capitalism. International Relations 17(2):153173. $[\mathrm{TH}]$

2006. A critical naturalist approach to power and hegemony, analyzing giving practices. In Hegemony and power: consensus and coercion in contemporary politics. M. Haugaard and H. H. Lentner, eds. Pp. 151-167. Oxford: Lexington.

Hayter, T. 1971. Aid as imperialism. Harmondsworth, UK: Penguin. [STR]

Hénaff, Marcel. 2010a. The price of truth: gift, money and philosophy. Stanford, CA: Stanford University Press.

2010b. I/you: reciprocity, gift-giving and the third party. META: Research in Hermeneutics, Phenomenology, and Practical Philosophy 2(1): $57-83$.

Hever, S. 2015. How much international aid to Palestinians ends up in the Israeli economy? AidWatch Working Paper. http://goo.gl/RnV3f5. [AT]

Homans, George C. 1961. Social behavior, its elementary forms. London: Routledge.

Jad, Islah. 2007. NGOs: between buzzwords and social movements. Development in Practice 17(4-5):622-629.

Jones, Sam, and Finn Tarp. 2016. Does foreign aid harm political institutions? Journal of Development Economics 118:266-281.

Kanbur, Ravi. 2011. Poverty professionals and poverty. In Revolutionizing development. A. Cornwall and I. Scoones, eds. Pp. 211-216. London: Earthscan.

Kapoor, Ilan. 2008. The postcolonial politics of development. London: Routledge.

Karagiannis, Nathalie. 2004. Avoiding responsibility: the politics and discourse of European development. London: Pluto.

Keating, Michael, Anne Le More, and Robert Lowe, eds. 2005. Aid, diplomacy and facts on the ground. London: RIIA.

Keohane, Robert. 1986. Reciprocity in international relations. Internationa Organization 40(1):1-27.

Khalidi, R., and S. Samour. 2011. Neoliberalism as liberation: the Statehood Program and the remaking of the Palestinian National Movement. Lournal of Palestine Studies 40(2):6-25. [STR]

Khan, Farzad R., R. Westwood, and D. M. Boje. 2011. 'I feel like a foreign agent': NGOs and corporate social responsibility interventions into Third World child labor. Human Relations 63(9):1417-1438.

Khouri, Rami. 2011. Drop the Orientalist term, Arab Spring. Daily Star (Beirut), August 17.

Kolm, Serge-Christophe, and Jean Mercier Ythier, eds. 2006. Handbook of the economics of giving, altruism and reciprocity. Amsterdam: Elsevier.

Komter, Aafke E. 2005. Social solidarity and the gift. Cambridge: Cambridge University Press.

Konstan, David. 2001. Pity transformed. New York: Bloomsbury.
Kowalski, R. 2011. The gift: Marcel Mauss and international aid. Iournal of Comparative Social Welfare 27(3):189-203.

Lazarus, Ned, and Michelle I. Gawerc. 2015. The unintended impacts of 'material support': US anti-terrorism regulations and Israeli/Palestinian peacebuilding. Iournal of Peacebuilding and Development 10(2):68-73.

Le More, Anne. 2008. International assistance to the Palestinians after Oslo: political guilt, wasted money. London: Routledge.

Lemay-Hébert, Nicolas. 2009. Statebuilding without nation-building? legitimacy, state failure and the limits of the institutionalist approach. Journal of Intervention and Statebuilding 3(1):21-45.

Lentin, Ronit. 2008. Thinking Palestine. London: Zed.

Mauss, Marcel. 1967 (1925). The gift: forms and functions of exchange in archaic societies. Ian Cunnison, trans. New York: Norton. [TH]

. 1990 (1925). The gift: forms and reason for exchange in archaic societies. W. D. Halls, trans. New York: Norton. [TH]

- 2002 (1925). The gift: forms and functions of exchange in archaic societies. London: Routledge.

Mawdsley, Emma. 2012. The changing geographies of foreign aid and development cooperation: contributions from gift theory. Transactions 37(2):256272.

McMillan, David V., and D. M. Chavis. 1986. Sense of community: a definition and theory. Journal of Community Psychology 14:6-23.

MERP (Middle East Report). 2000. Critiquing NGOs: assessing the last decade. Middle East Report 30(214). http://www.merip.org/mer/mer214/.

Miller, William Ian. 1995. Humiliation: and other essays on honor, social discomfort, and violence. Ithaca, NY: Cornell University Press.

Mosley, Paul. 1987. Overseas aid: its defense and reform. Brighton, UK: Wheatsheaf. Mosse, David. 2005. Cultivating development. London: Pluto.

Moyo, Dambisa. 2010. Dead aid: why aid is not working and how there is another way for Africa. New York: Penguin.

Murad, Nora. 2014. Donor complicity in Israel's violations of Palestinian rights. Policy Brief. Ramallah, West Bank: Al-Shabaka.

Nabulsi, Karma. 2005. The state-building project: what went wrong? In Aid, diplomacy and facts on the ground. Anne Le More, Michael Keating, and Robert Lowe, eds. Pp. 117-128. London: RIIA.

Nakhleh, Khalil. 2004. The myth of Palestinian development: political aid and sustainable deceit. Jerusalem, Israel: Palestinian Academic Society for the Study of International Affairs.

2013. Globalized Palestine: the national sell-out of a homeland. Trenton, NJ.: Red Sea.

Nussbaum, M. C. 2001. Upheavals of thought: the intelligence of emotions. Cambridge: Cambridge University Press. [AF]

- 2013. Political emotions: why love matters for justice. Cambridge, MA: Harvard University Press. [AF]

OECD (Organization for Economic Cooperation and Development). 2015. Inclusive partnerships for effective development co-operation. In Development co-operation report 2015: making partnerships effective coalitions for action. Paris: OECD.

_ 2016. QWIDS: query wizard for international development statistics. Paris: OECD. http://stats.oecd.org/qwids/. [AT]

Osteen, Mark, ed. 2002. The question of the gift: essays across disciplines. New York: Routledge.

Ostrander, Susan A. 1993. Diversity and democracy in philanthropic organizations: the case of Haymarket People's Fund. In Governing, leading and managing nonprofit organizations. Dennis Young, Robert M. Hollister, and Virginia A. Hodgkinson, eds. Pp. 193-213. San Francisco: Jossey-Bass. [TH]

Paragi, Beáta. 2012a. First impressions and perceived roles: Palestinian perceptions on foreign aid. Society and Economy 35(1):389-410.

. 2012b. The spiritual essence: Palestinian perceptions on foreign aidconditionality and reciprocity. Journal International Political Anthropology 5(1):3-28.

2015a. Divide et impera? foreign aid interventions in the Middle East and North Africa region. Journal of Intervention and Statebuilding 10(2):200222.

2015b. Eastern and Western perceptions on EU aid in light of the Arab Spring. Democracy and Security 11(1):60-82.

. 2016a. Foreign aid and the Arab Spring. In Regional integration and national disintegration in the post-Arab Spring Middle East. Imad El-Anis and Natasha Underhill, eds. Pp. 72-97. Newcastle-upon-Tyne, UK: Cambridge Scholar.

- 2016b. Hegemonic solidarity? Palestinian NGO perceptions on power and cooperation with their donors. Alternatives: Global, Local, and Political. http://journals.sagepub.com/doi/abs/10.1177/0304375416684855. 
2017. Cultures of (dis)trust: shame and solidarity from recipient NGO perspectives. International Journal of Cultural Studies. http://journals sagepub.com/doi/abs/10.1177/1367877917704237.

Parry, Jonathan. 1986. The gift, the Indian gift, and the "Indian Gift." Man 21 (3):454-473. [TH]

Peres, Simon. 1993. The new Middle East. New York: Holt.

Polanyi, Karl. 2001. The great transformation. Boston: Beacon.

Pyyhtinen, Olli. 2014. The gift and its paradoxes, beyond Mauss. Farnham, UK: Ashgate.

Qian, Nancy. 2015. Making progress on foreign aid. Annual Review of Eco nomics 7:277-308

Rankin, Jennifer. 2017. Hungary investigated by EU over law threatening top university. Guardian, 12 April 2017. https://www.theguardian.com/world /2017/apr/12/frans-timmermans-eu-commission-central-european-university -budapest-hungary.

Razack, Sherene H. 2007. Stealing the pain of others: reflections on Canadian humanitarian responses. Review of Education, Pedagogy and Cultural Studies 29 (4):375-394.

Rist, Gilbert. 2014 (2003). The history of development: from Western origins to global faith. London: Zed.

Sahlins, Marshall. 1972. Stone Age economics. Chicago: Aldine Transaction.

Said, Nader. 2005. Palestinian perceptions of international assistance. In Aid, diplomacy and facts on the ground. Anne Le More, Michael Keating, and Robert Lowe, eds. Pp. 99-107. London: RIIA.

Sandel, Michael. 2011. What money can't buy? the moral limits of markets. New York: Farrar, Straus, and Giroux.

Schrift, Alan D., ed. 1997. The logic of the gift: toward an ethic of generosity. New York: Routledge.

Scott, James C. 1998. Seeing like a state. New Haven, CT: Yale University Press.

Serres, Michel. 1982. The parasite. Minneapolis: University of Minnesota Press.

Shalhoub-Kevorkian, Nadera, A. Griecci Woodsum, H. Zu'bi, and R. Busbridge. 2014. Funding pain: Bedouin women and political economy in the Naqab. Feminist Economics 20(4):164-186.

Simmel, Georg. 1965. The poor. Social Problems 13(2):118-140.

Sontag, S. 2003. Regarding the pain of others. New York: Picador.

Sørensen, Georg. 1993. Political conditionality. London: Frank Cass.
1995. Conditionality, democracy and development. In Aid and political conditionality. Olav Stokke, ed. Pp. 392-409. London: Cass.

Spivak, Gayatri Chakravorty. 1999. A critique of postcolonial reason. Cambridge, MA: Harvard University Press.

Springer, Joanna, 2015. Assessing donor-driven reforms in the Palestinian Authority: building the state or sustaining status quo. Iournal of Peacebuilding and Development 10(2):1-19.

Stirrat, R. L., and Heiko Henkel. 1997. The development gift: the problem of reciprocity in the NGO world. Annals of the American Academy of Political and Social Science 55(4):66-80.

Stokke, Olav, ed. 1995. Aid and political conditionality. London: Cass.

Tabar, Linda, ed. 2015. Critical readings of development under colonialism: towards a political economy for liberation in the occupied Palestinian Territories. Ramallah, West Bank: Bir Zeit. http://home.birzeit.edu/cds/new-cds /sites/default/files/sites/default/files/publications/CRITICAL-READINGS1 \%20\%25281\%2529\%20(1).pdf.

Taghdisi-Rad, Sahar. 2011. The political economy of aid in Palestine, relief from conflict or development delayed? London: Routledge.

Tartir, Alaa. 2014. Criminalising resistance, entrenching neoliberalism: the Fayyadist paradigm in occupied Palestine. $\mathrm{PhD}$ dissertation, London School of Economics.

Uphoff, Norman. 1993. Grassroots organizations and NGOs in rural development. World Development 21(4):607-622.

Van Norden, Richard. 2013. Open access: the true cost of science publishing. Nature 495(7442):426-429.

WHS (World Humanitarian Summit). 2014. Preparatory stakeholder analysis World Humanitarian Summit Regional Consultation for the Middle East and North Africa. Istanbul, Turkey: WHS.

Watenpaugh, Keith David. 2015. Bread from stones: the Middle East and the making of modern humanitarianism. Berkeley: University of California Press.

Wildeman, Jeremy, and Alaa Tartir. 2014. Unwilling to change, determined to fail: donor aid in occupied Palestine in the aftermath of the Arab Uprisings. Mediterranean Politics 19(3):431-449.

Wildeman, J., and A. Tartir. 2013. Can Oslo's failed aid model be laid to rest? Al-Shabaka Policy Brief. https://goo.gl/KxoAZ7. [AT]

Wood, Reed M., and C. Sullivan. 2015. Doing harm by doing good? the negative externalities of humanitarian aid provision during civil conflict. Working Paper 11. Williamsburg, VA: AidData. 